\title{
Additive manufacturing technologies for biomedical engineering applications: Research trends and scientific impact
}

\author{
Enara Zarrabeitia-Bilbao; Izaskun Álvarez-Meaza; Rosa-María Río-Belver; \\ Gaizka Garechana-Anacabe
}

How to cite this article:

Zarrabeitia-Bilbao, Enara; Álvarez-Meaza, Izaskun; Río-Belver, Rosa-María; Garechana-Anacabe, Gaizka (2019). "Additive manufacturing technologies for biomedical engineering applications: Research trends and scientific impact". El profesional de la información, v. 28, n. 2, e280220.

https://doi.org/10.3145/epi.2019.mar.20

Article received on 9 November 2018 Approved on 11 March 2019

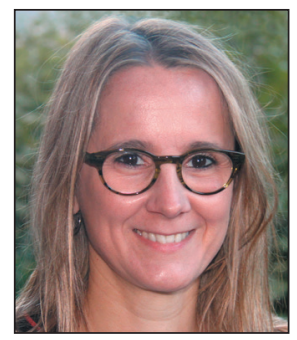

Enara Zarrabeitia-Bilbao https://orcid.org/0000-0002-2347-3885

University of the Basque Country (UPV/EHU) Faculty of Engineering in Bilbao Industrial Organization and Management Engineering Department

Plaza Ingeniero Torres Quevedo, 1. 48013 Bilbao, Spain

enara.zarrabeitia@ehu.eus

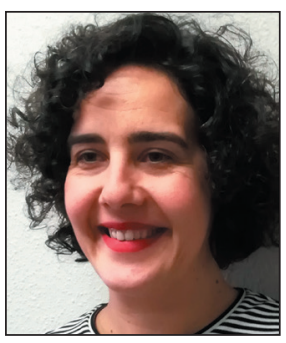

Izaskun Álvarez-Meaza

https://orcid.org/0000-0002-2110-0719

University of the Basque Country (UPV/EHU)

Faculty of Engineering in Bilbao

Industrial Organization and Management

Engineering Department

Plaza Ingeniero Torres Quevedo, 1. 48013

Bilbao, Spain

izaskun.alvarez@ehu.eus

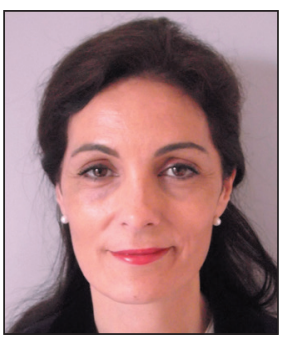

\section{Rosa-María Río-Belver}

https://orcid.org/0000-0002-4244-9098

University of the Basque Country (UPV/EHU)

Faculty of Engineering in Vitoria-Gasteiz

Industrial Organization and Management

Engineering Department

C/ Nieves Cano 12, 01007 Vitoria, Spain

rosamaria.rio@ehu.eus

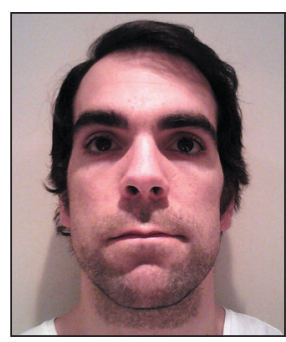

Gaizka Garechana-Anacabe

https://orcid.org/0000-0002-1913-3239

University of the Basque Country (UPV/EHU) Faculty of Economics and Business in Bilbao (Elcano)

Industrial Organization and Management

Engineering Department

C/ Elcano 2148008 Bilbao, Spain

gaizka.garechana@ehu.eus

\begin{abstract}
Additive Manufacturing (AM) technologies, technologies that produce three-dimensional parts layer by layer from a material, have the potential to revolutionize the paradigm of manufacturing. Furthermore, in recent years AM technologies have sparked intense interest for developing medical implants, devices, and scaffolds. In this context, the main objective of this article is to present an overall view of the trends and the impact of the research carried out in AM technologies for biomedical engineering applications. Therefore, to achieve the main objective, a research trend and scientific impact analysis model was designed and implemented, to carry out a bibliometric indicator analysis, in general, and a web indicator analysis, in particular. The findings obtained will advance the means of visualizing the state of research in AM for biomedical engineering technologies.
\end{abstract}

\section{Keywords}

Additive manufacturing; Biomedical engineering; Bibliometric analysis; Web indicators; Webometrics. 


\section{Introduction}

The term "Industry 4.0 " is used to indicate the fourth industrial revolution, a new industrial model enabled by the introduction of the Internet of Things into the production and manufacturing environment (Tjahjono et al., 2017). To achieve this new paradigm, Industry 4.0 is based on a set of key technologies that, when combined, make this new industrial model possible. Thereby, nine technologies are transforming industrial production: Big data and analytics, autonomous robots, simulation, horizontal and vertical system integration, the industrial internet of things, cyber security, the cloud, augmented reality, and additive manufacturing (AM).

In this context, one of the most visible elements of Industry 4.0 is the growth of AM technologies (Cruickshank, 2017), technologies that can produce desired parts faster, more flexibly and more precisely than ever before, i.e., technologies that can produce higher-quality goods at reduced costs.

These technologies produce three-dimensional parts layer by layer from a material and have the potential to revolutionize the paradigm of manufacturing (Quarshie et al., 2012). In terms of industry specifics, AM has thrived considerably in particular areas over the last few years (AM Platform, 2014). The technology cuts across a large number of industries and applications, and that is part of what makes its potential so compelling. Aerospace, automotive, and medical products, among others, will drive AM into the future (Bourell; Leu; Rosen, 2009). Specifically, in recent years AM technologies have sparked intense interest for developing, among other things, medical implants, devices, and medical scaffolds (Singh; Ramakrishna, 2017).

Thus, in recent years the research community has worked to develop and improve the knowledge landscape of these research fields; however, the trends and the impact of such work have not been analyzed. Assessing trends and the value of research is becoming increasingly important (Thelwall; Kousha, 2015a; 2015b; Thelwall, 2016; Filser; Da-Silva; De-Oliveira, 2017) and the need to evaluate the research carried out by organizations involved in research and development and innovation (R\&D\&I) processes has increased dramatically in recent years.

In this way, the main aims of this study are to present an overall view of the trends and the impact of the research carried out in AM technologies for biomedical engineering applications.

The findings obtained will advance means of visualizing the state of research into AM technologies for biomedical applications. This will help, on the one hand, to better understand how structured this research field is and how it is growing, as well as identify the major actors. On the other hand, it will provide a better understanding of the impact or the benefits that research into these technologies has in different fields. This study will make it possible to know the evolution of the existing literature on technologies that will change, among other things, productive systems, skills, and well-being (OECD, 2016), and that will have great implications for policy makers (Campbell et al., 2011).

\section{Research methodology}

The main goal of the study is to present an overall view of the trends and the impact of research carried out on a technology. To do so, this article carries out a bibliometric indicator analysis, in general, and a web indicator analysis in particular.

A bibliometric analysis is a quantitative method that, based on analysis of related publications, allows the knowledge structure and the development of research fields to be examined (Jing; Qinghua; Landström, 2017). In this way, the simplest bibliometric indicator is the number of publications in a particular field. However, other indicators, such as cited references and citation counts, have gained importance for evaluating research performance and impact (Holmberg, 2015; Marx; Bornmann, 2016).

Web indicator analysis is a quantitative method that evaluates web indicators, where a web indicator is a number that is ideally associated with an aspect of research performance or impact, and that is derived from the Web and in no way based on counts of citations from academic journal articles. Therefore, different web

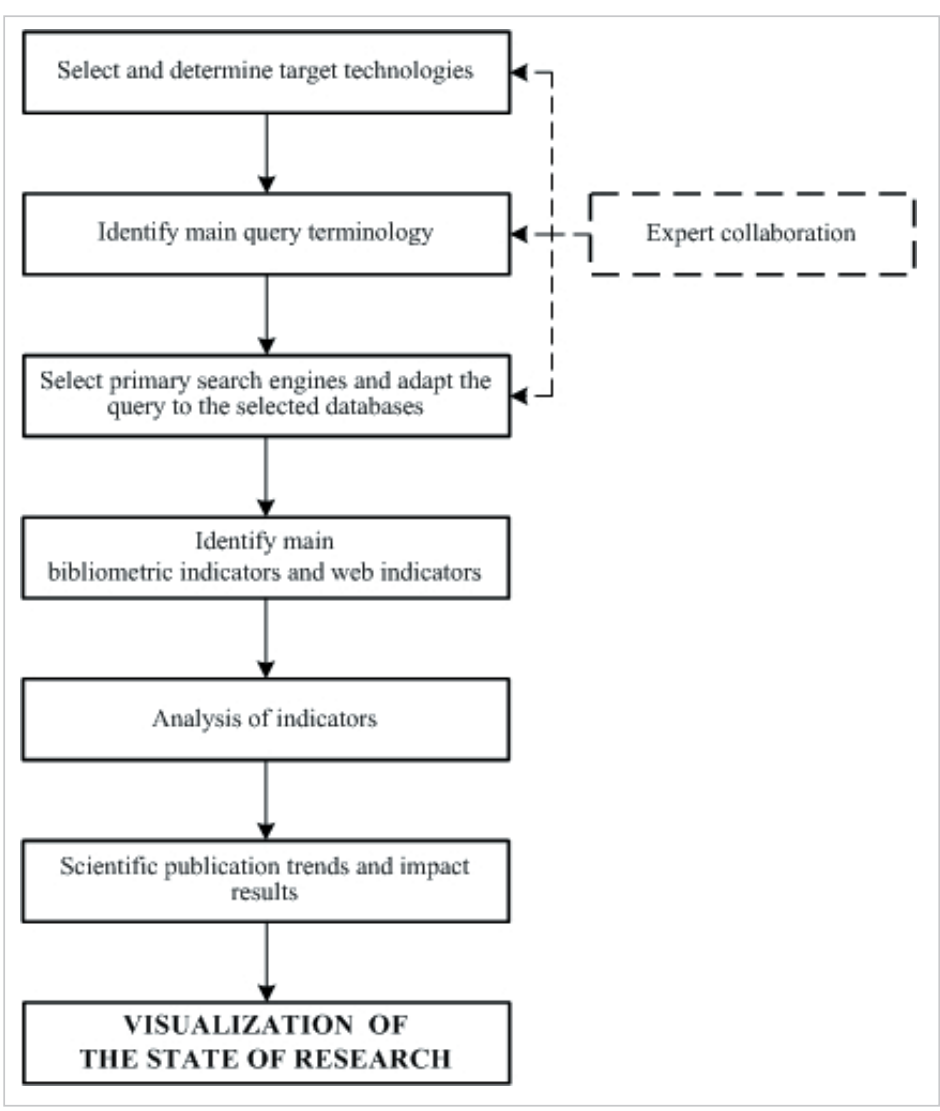

Figure 1. Workflow of research trends and scientific impact analysis model 
overall view of the trends and the impact of the research carried out in AM technologies for biomedical engineering applications (see table 1 and figure 3).

Table 1. Analysis of the results obtained for determining research trends and impact in AM technologies for biomedical engineering applications

\begin{tabular}{|c|c|c|}
\hline \multicolumn{3}{|c|}{ Research trends } \\
\hline Bibliometric indicators & Variables analyzed & Software to gather, clean, analyze and visualize articles data \\
\hline $\begin{array}{l}\text { - Number of articles published } \\
\text { - Cited references of the articles } \\
\text { studied }\end{array}$ & $\begin{array}{l}\text { - Publication year } \\
\text { - Country } \\
\text { - Affiliation } \\
\text { - Journal } \\
\text { - Author } \\
\text { - Research area } \\
\text { - Keywords }\end{array}$ & \multirow[t]{2}{*}{$\begin{array}{l}\text { - VantagePoint v. } 10 \\
\text { A powerful text-mining tool for discovering knowledge in } \\
\text { search results from patent and literature databases (Vantage- } \\
\text { Point, 2018). } \\
\text { - VOSViewer } \\
\text { Software that allows the visualization of bibliometric networ- } \\
\text { ks (VOSviewer, 2018). }\end{array}$} \\
\hline \multicolumn{2}{|l|}{$\begin{array}{l}\text { Type of documents and time span: } \\
\text { Scientific articles, from } 2000 \text { to } 2017\end{array}$} & \\
\hline \multicolumn{3}{|c|}{ Research impact } \\
\hline Bibliometric indicator & Impact type & Software to gather and analyze web data \\
\hline - Citation counts & - Academic impact & \multirow{5}{*}{$\begin{array}{l}\text { Webometrics Analyst } 2.0 \\
\text { Free software designed to conduct automatic web analyses of } \\
\text { various types for social science research purposes (Thelwall, 2009a; } \\
\text { 2009b). }\end{array}$} \\
\hline Web indicator & Impact type & \\
\hline $\begin{array}{l}\text { - Mendeley readers } \\
\text { - Wikipedia citations }\end{array}$ & - Academic impact & \\
\hline - Google Patents citations & - Industrial and commercial impact & \\
\hline \multicolumn{2}{|c|}{$\begin{array}{l}\text { Type of documents and time span: Scientific articles (from World, USA } \\
\text { and China), from } 2006 \text { to } 2015\end{array}$} & \\
\hline
\end{tabular}

RESEARCH TRENDS AND IMPACT

\begin{tabular}{|c|c|c|}
\hline \multirow{2}{*}{$\begin{array}{l}\text { Where does knowledge come from? } \\
\qquad- \text { Knowledge input }\end{array}$} & $\begin{array}{l}\text { When, where, who and what } \\
\text { is researching? }\end{array}$ & \multirow{2}{*}{$\begin{array}{l}\text { What is the impact of the research? } \\
\text {-Knowledge output } \longrightarrow\end{array}$} \\
\hline & Research being carried out & \\
\hline $\begin{array}{l}\text { - Cited references of the articles } \\
\text { studied }\end{array}$ & - Number a of articles published & $\begin{array}{l}\text { - } \text { Citation counts } \\
\text { - Mendeley readers } \\
\text { - Wikipedia citations } \\
\text { - Google patents citations }\end{array}$ \\
\hline
\end{tabular}

Figure 3. Research trends and scientific impact analysis model to determine research trends and impact in AM technologies for biomedical engineering applications

The two bibliometric indicators used to analyze research trend performance from the chosen variables (Publication year, Country, Affiliation, Journal, Author, Research area, and Keywords) were the usual bibliometric indicator number of articles published (when, where, who, and what is researching) and cited references of the articles studied (where does knowledge come from). The first was a quantitative output of research activity while the second brought a change of perspective and measured what the knowledge sources of AM technologies for biomedical engineering applications were (Diem; Wolter, 2013; Holmberg, 2015; Marx; Bornmann, 2016; Filser; Da-Silva; De-Oliveira, 2017).

It was not possible to obtain directly the country and the affiliation of the cited references from the WoS database. Therefore, all cited references under study were obtained from their DOI from the WoS database.

The software used to gather, clean, analyze, and visualize article data were VantagePoint and VOSviewer. As far as the mapping and clustering of bibliographic networks was concerned, the VOS mapping technique was used (Van-Eck; Waltman, 2007). We used the VOSviewer software to apply this technique (Van-Eck; Waltman, 2011). In this case, the mapping technique was performed on the basis of the co-occurrence matrix and the similarity matrix, the latter being obtained from the application in the co-occurrence matrix similarity measures, specifically known as the associative strength (Van-Eck; Waltman, 2009; 2010). The map that was defined based on similarity indicated the degree of relationship between the terms, i.e., a close position indicated a high degree of relationship between the items. In addition, the clustering technique, based on the VOS mapping technique (Waltman; Van-Eck; Noyons, 2010), made it possible to group items into research fields. 
As far as the analysis of the impact of research was concerned, we used another bibliometric indicator called citation counts, i.e., how often each of the publications was cited in the WoS database. In addition, web indicators were also used to measure the impact of publications. Although there are many different types of web indicators, in this case, academic plus industrial and commercial impact indicators were used. The academic impact was measured from Mendeley readers (Mendeley readers of lists of scientific articles gathered) and Wikipedia citations (Wikipedia citations to a list of scientific articles gathered). And finally, the industrial and commercial impact was measured from Google Patents citations (citations from patents to a list of scientific articles gathered) (Thelwall, 2016). The software used to gather and analyze web data was Webometrics Analyst (Thelwall, 2009a; 2009b).

The type of documents analyzed was articles because, when calculating field normalized indicators, it is best to analyze only one document type-usually articles (Thelwall, 2018).

In the case of bibliometric analysis, articles published from 2000 to 2017 were analyzed. For impact indicator analysis, the years chosen for the analysis were from 2006 to 2015, i.e. a decade. The first few years were ignored due to the scarcity of results and it was decided that 2015 would be the last year analyzed as this left a performance interval of more than two years until the present, making it possible to analyze the impact of recently published articles in the field of interest. Also, it was analyzed if the research from predominant countries (countries with the highest number of publications) has higher impact than the world average.

\section{Results}

The query found 1,223 journal articles published from 2000 to 2017 concerning AM technologies for biomedical engineering applications (see appendix), and 33,868 references cited in those articles.

In order to analyze the most significant references, only those that were cited more than 5 times were taken into account. Thus, the sample was reduced to 778 documents. From those 778 documents it was possible to obtain the DOI of only 744 references, and finally, it was possible to find 737 of those documents in the Web of Science Core Collection. Therefore, the number of references analyzed was 737.

For impact analysis, the query used recovered the number of articles shown in Table 2 (see appendix).

Table 2. Number of articles recovered for impact analysis

\begin{tabular}{|c|c|c|c|c|c|c|c|c|c|c|}
\hline Year & 2006 & 2007 & 2008 & 2009 & 2010 & 2011 & 2012 & 2013 & 2014 & 2015 \\
\hline Articles & 31 & 32 & 46 & 64 & 56 & 64 & 66 & 100 & 108 & 158 \\
\hline
\end{tabular}

The analysis of the results obtained is described in the following sections.

\subsection{Research trends}

To identify where and how technologies emerge, scientific publication trends have been drawn after the results obtained from WoS analyses. More specifically, the section structures and analyzes the variables "Publication year", "Country", "Affiliation", "Author", "Journal", "Keywords", and "Research area" of the articles retrieved, and their cites, in AM technologies for biomedical engineering applications.

\subsubsection{Publication year analysis}

Although there were articles published after 2000, the greatest activity was in recent years. Figure 4 shows that article publication growth was exponential (the coefficient of determination is $R^{2}=0.8857$ ) and that the instant growth rate was 0.2943 .

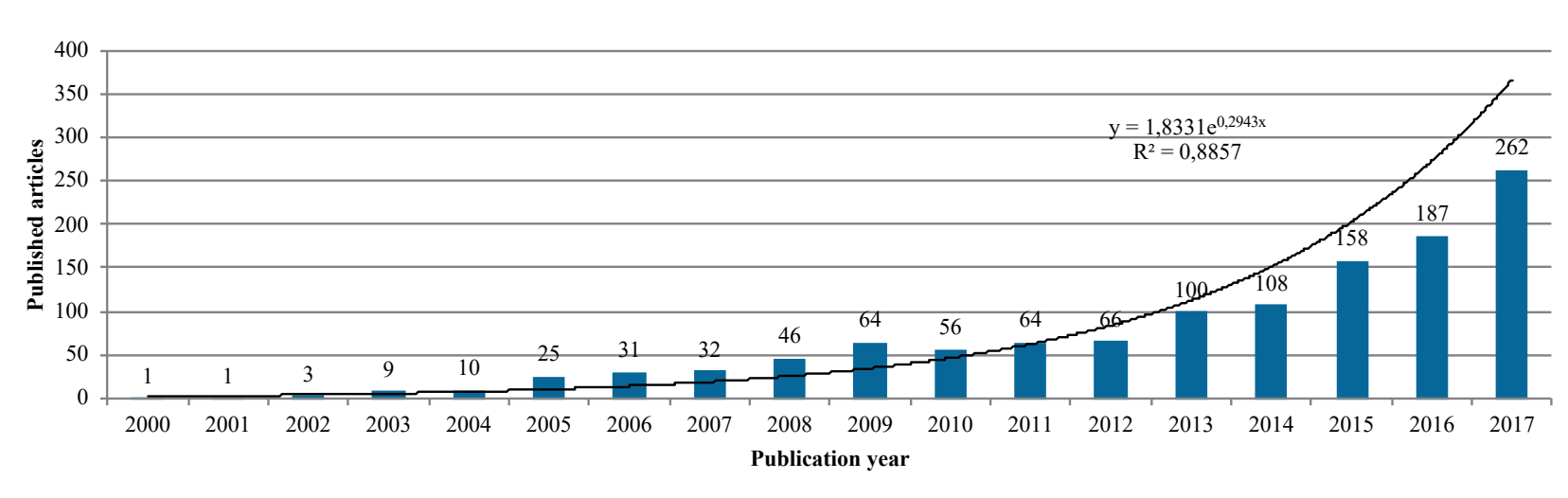

Figure 4. Annual article publications in AM for biomedical engineering applications from 2000 to 2017 
It can be seen that, in recent years, AM technologies for biomedical engineering applications have become of growing interest and with very intensive article publication.

Figure 4 shows that article publication growth follows the bibliometric law of exponential growth (Derek J. de Solla Price's law) (Ardanuy, 2012). According to that law, the scientific production in this field is in the phase of exponential growth, i.e., it is an emerging research front.

\subsubsection{Country analysis}

The predominant country, by far, with the highest number of publications, and with the highest number of cited references, is the USA (see table 3). More than $34 \%$ of all articles published on AM technologies for biomedical engineering applications, and more than $50 \%$ of the references analyzed, were from that country. Therefore, the country with the greatest research activity in that field, and providing most knowledge, was the USA.

China also has extensive research activity; however, its contribution to this particular field has been secondary: despite being the second country with the highest number of publications ( $17.09 \%$ of the articles), it is relegated to ninth position in the rank of cited countries (3.93\% of the cited references).

In addition, except on two occasions, there was a relationship between the countries that provided knowledge (countries referenced) and the countries that were researching the subject in question.

Table 3. The 10 most frequent affiliation countries and the 10 most cited countries

\begin{tabular}{|c|c|c|c|c|c|c|c|}
\hline \multicolumn{4}{|c|}{$\begin{array}{l}\text { Research carried out in AM for BE } \\
\text { (Where researching is) }\end{array}$} & \multicolumn{4}{|c|}{$\begin{array}{l}\text { Research used to develop research in AM for BE } \\
\text { (Where knowledge comes from) }\end{array}$} \\
\hline$\#$ & Country & \# of articles & $\%$ of articles & $\#$ & Cited Country & \# of times cited & $\%$ of references \\
\hline 1 & USA & 425 & $34.75 \%$ & 1 & USA & 375 & $50.88 \%$ \\
\hline 2 & China & 209 & $17.09 \%$ & 2 & Germany & 72 & $9.77 \%$ \\
\hline 3 & Germany & 121 & $9.89 \%$ & 3 & Netherlands & 54 & $7.33 \%$ \\
\hline 4 & South Korea & 100 & $8.18 \%$ & 4 & South Korea & 47 & $6.38 \%$ \\
\hline 5 & England & 77 & $6.30 \%$ & 5 & England & 41 & $5.56 \%$ \\
\hline 6 & Italy & 69 & $5.64 \%$ & 6 & Japan & 33 & $4.48 \%$ \\
\hline 7 & Japan & 68 & $5.56 \%$ & 7 & France & 32 & $4.34 \%$ \\
\hline 8 & Netherlands & 61 & $4.99 \%$ & 8 & Singapore & 32 & $4.34 \%$ \\
\hline 9 & Australia & 52 & $4.25 \%$ & 9 & China & 29 & $3.93 \%$ \\
\hline 10 & Canada & 48 & $3.92 \%$ & 10 & Australia & 27 & $3.66 \%$ \\
\hline
\end{tabular}

\subsubsection{Institution analysis}

The top publishing and cited institutions are universities (see table 4).

The institution that has published the most articles about AM technologies for biomedical engineering applications is the Massachusetts Institute of Technology (36 articles) and the institution that has been the most cited is Harvard University (72 articles), closely followed by the Massachusetts Institute of Technology (70 articles), both from the USA.

On five occasions, the institutions from which the knowledge comes from matches the institution where the research is being developed.

\subsubsection{Journal analysis}

Table 5 provides an overview of the 10 journals with the most occurrences.

The journal Biomaterials was the most prolific journal in AM technologies for biomedical engineering applications and also the most cited.

As expected, all the journals that publish research carried out in AM for biomedical engineering are journals that specialize in biomedical engineering. Other less specific journals have also been cited, therefore the knowledge also comes from other research fields such as life and physical sciences. Even so, in this case too, there was some correspondence between journals that published articles about AM technologies for biomedical engineering applications and journals cited in these articles. 
Table 4. The 10 most frequent organizational affiliations and the 10 most cited organizational affiliations

\begin{tabular}{|c|c|c|c|c|c|c|c|c|c|c|c|}
\hline \multicolumn{6}{|c|}{$\begin{array}{l}\text { Research carried out in AM for BE } \\
\text { (Where researching is) }\end{array}$} & \multicolumn{6}{|c|}{$\begin{array}{l}\text { Research used to develop research in AM for BE } \\
\text { (Where knowledge comes from) }\end{array}$} \\
\hline$\#$ & Institution & $\begin{array}{l}\text { Type of } \\
\text { institu- } \\
\text { tion }\end{array}$ & Country & $\begin{array}{l}\text { \# of ar- } \\
\text { ticles }\end{array}$ & $\begin{array}{c}\% \text { of } \\
\text { articles }\end{array}$ & $\#$ & $\begin{array}{l}\text { Cited institu- } \\
\text { tion }\end{array}$ & $\begin{array}{l}\text { Type of } \\
\text { institu- } \\
\text { tion }\end{array}$ & Country & $\begin{array}{l}\text { \# of } \\
\text { times } \\
\text { cited }\end{array}$ & $\%$ of cites \\
\hline 1 & MIT & University & USA & 36 & $2.94 \%$ & 1 & Harvard Univ. & University & USA & 72 & $9.77 \%$ \\
\hline 2 & $\begin{array}{l}\text { Pohang Univ. } \\
\text { Sci. \& Technol. }\end{array}$ & University & $\begin{array}{l}\text { South } \\
\text { Korea }\end{array}$ & 33 & $2.70 \%$ & 2 & MIT & University & USA & 70 & $9.50 \%$ \\
\hline 3 & Harvard Univ. & University & USA & 32 & $2.62 \%$ & 3 & Univ. Michigan & University & USA & 32 & $4.34 \%$ \\
\hline 4 & Zhejiang Univ. & University & China & 30 & $2.45 \%$ & 4 & Univ. Twente & University & Netherlands & 22 & $2.99 \%$ \\
\hline 5 & Univ. Twente & University & $\begin{array}{l}\text { Nether- } \\
\text { lands }\end{array}$ & 27 & $2.21 \%$ & 5 & Rice Univ. & University & USA & 20 & $2.71 \%$ \\
\hline 6 & $\begin{array}{l}\text { Queensland } \\
\text { Univ. Technol. }\end{array}$ & University & Australia & 19 & $1.55 \%$ & 6 & $\begin{array}{l}\text { Pohang Univ. Sci. } \\
\text { \& Technol. }\end{array}$ & University & South Korea & 19 & $2.58 \%$ \\
\hline 7 & $\begin{array}{l}\text { Shanghai Jiao } \\
\text { Tong Univ. }\end{array}$ & University & China & 18 & $1.47 \%$ & 7 & Univ. Utrecht & University & Netherlands & 19 & $2.58 \%$ \\
\hline 8 & Univ. Michigan & University & USA & 18 & $1.47 \%$ & 8 & Clemson Univ. & University & USA & 18 & $2.44 \%$ \\
\hline 9 & $\begin{array}{l}\text { Univ. Med. Ctr. } \\
\text { Utrecht }\end{array}$ & University & $\begin{array}{l}\text { Nether- } \\
\text { lands }\end{array}$ & 17 & $1.39 \%$ & 9 & Drexel Univ. & University & USA & 18 & $2.44 \%$ \\
\hline 10 & Univ. Wurzburg & University & Germany & 17 & $1.39 \%$ & 10 & $\begin{array}{l}\text { Natl. Univ. Sin- } \\
\text { gapore }\end{array}$ & University & Singapore & 18 & $2.44 \%$ \\
\hline
\end{tabular}

Table 5. The 10 most frequent journals

\begin{tabular}{|l|l|l|l|l|l|l|l|l|c|l|l|l|}
\hline \multicolumn{3}{|c|}{ Research carried out in AM for BE (Who researching is) } & \multicolumn{3}{|c|}{ Research used to develop research in AM for BE (Who knowled- } \\
ge comes from)
\end{tabular}




\begin{tabular}{|c|c|c|c|c|c|c|c|c|c|c|c|c|c|}
\hline \multirow{6}{*}{5} & \multirow{6}{*}{$\begin{array}{l}\text { Adv. Healthc. } \\
\text { Mater }\end{array}$} & \multirow{6}{*}{60} & \multirow{2}{*}{$\begin{array}{l}\text { Engineering, } \\
\text { Biomedical }\end{array}$} & \multirow[t]{2}{*}{ Q1 } & \multirow{6}{*}{5.609} & \multirow{6}{*}{$4.91 \%$} & \multirow{6}{*}{5} & \multirow{6}{*}{ Adv. Mater } & \multirow{6}{*}{22} & $\begin{array}{l}\text { Chemistry, } \\
\text { Multidiscipli- } \\
\text { nary }\end{array}$ & Q1 & & \multirow{6}{*}{$2.99 \%$} \\
\hline & & & & & & & & & & $\begin{array}{l}\text { Chemistry, } \\
\text { Physical }\end{array}$ & Q1 & & \\
\hline & & & \multirow{2}{*}{$\begin{array}{l}\text { Materials scien- } \\
\text { ce, Biomaterials }\end{array}$} & \multirow[t]{2}{*}{ Q1 } & & & & & & $\begin{array}{l}\text { Materials } \\
\text { science, } \\
\text { Multidiscipli- } \\
\text { nary }\end{array}$ & Q1 & & \\
\hline & & & & & & & & & & $\begin{array}{l}\text { Nanoscience } \\
\& \text { Nanotech- } \\
\text { nology }\end{array}$ & Q1 & & \\
\hline & & & \multirow{2}{*}{$\begin{array}{l}\text { Nanoscience \& } \\
\text { Nanotechnology }\end{array}$} & \multirow[b]{2}{*}{ Q2 } & & & & & & $\begin{array}{l}\text { Physics, } \\
\text { Applied }\end{array}$ & Q1 & & \\
\hline & & & & & & & & & & $\begin{array}{l}\text { Physics, } \\
\text { Condensed } \\
\text { matter }\end{array}$ & Q1 & & \\
\hline \multirow{3}{*}{6} & \multirow{3}{*}{$\begin{array}{l}\text { J. Mater. } \\
\text { Sci.-Mater. } \\
\text { Med }\end{array}$} & \multirow{3}{*}{56} & $\begin{array}{l}\text { Engineering, } \\
\text { Biomedical }\end{array}$ & Q2 & \multirow{3}{*}{2.448} & \multirow{3}{*}{$4.58 \%$} & \multirow{3}{*}{6} & \multirow{3}{*}{$\begin{array}{l}\text { Biomacromo- } \\
\text { lecules }\end{array}$} & \multirow{3}{*}{20} & $\begin{array}{l}\text { Biochemistry } \\
\text { \& Molecular } \\
\text { biology }\end{array}$ & Q1 & \multirow{3}{*}{5.738} & \multirow{3}{*}{$2.71 \%$} \\
\hline & & & \multirow{2}{*}{$\begin{array}{l}\text { Materials scien- } \\
\text { ce, Biomaterials }\end{array}$} & \multirow{2}{*}{ Q3 } & & & & & & $\begin{array}{l}\text { Chemistry, } \\
\text { Organic }\end{array}$ & Q1 & & \\
\hline & & & & & & & & & & $\begin{array}{l}\text { Polymer } \\
\text { science }\end{array}$ & Q1 & & \\
\hline \multirow{2}{*}{7} & \multirow{2}{*}{$\begin{array}{l}\text { J. Mech. Be- } \\
\text { hav. Biomed. } \\
\text { Mater }\end{array}$} & \multirow{2}{*}{44} & $\begin{array}{l}\text { Engineering, } \\
\text { Biomedical }\end{array}$ & Q1 & \multirow{2}{*}{3.239} & \multirow{2}{*}{$3.60 \%$} & \multirow{2}{*}{7} & \multirow{2}{*}{ Science } & 10 & Multidis- & 1 & 11050 & 25006 \\
\hline & & & $\begin{array}{l}\text { Materials scien- } \\
\text { ce, Biomaterials }\end{array}$ & Q2 & & & & & (1) & sciences & Q & 41.050 & $2.50 \%$ \\
\hline & J. Biomed. & & $\begin{array}{l}\text { Engineering, } \\
\text { Biomedical }\end{array}$ & Q1 & 3.373 & & & & 18 & $\begin{array}{l}\text { Engineering, } \\
\text { Biomedical }\end{array}$ & Q1 & 3.652 & \\
\hline 8 & $\begin{array}{l}\text { Mater. Res. } \\
\text { Part B }\end{array}$ & 42 & $\begin{array}{l}\text { Materials scien- } \\
\text { ce, Biomaterials }\end{array}$ & Q2 & & $3.43 \%$ & 8 & Mater. Res & & $\begin{array}{l}\text { Materials } \\
\text { science, Bio- } \\
\text { materials }\end{array}$ & Q1 & $\begin{array}{c}(J C R \\
2004)\end{array}$ & $2.44 \%$ \\
\hline & & & & & & & & J. Biomed. & & $\begin{array}{l}\text { Engineering, } \\
\text { Biomedical }\end{array}$ & Q1 & & \\
\hline 9 & med. Eng & 41 & Biomedical & Q1 & 3.405 & $3.35 \%$ & 9 & $\begin{array}{l}\text { Mater. Res. } \\
\text { Part A }\end{array}$ & 17 & $\begin{array}{l}\text { Materials } \\
\text { science, Bio- } \\
\text { materials }\end{array}$ & Q2 & 3.231 & $2.31 \%$ \\
\hline & Proc. Inst. & & & & & & & J. Mater. & & $\begin{array}{l}\text { Engineering, } \\
\text { Biomedical }\end{array}$ & Q2 & & \\
\hline 10 & $\begin{array}{l}\text { Part H-J. Eng. } \\
\text { Med }\end{array}$ & 29 & Biomedical & Q4 & 1.124 & $2.37 \%$ & 10 & $\begin{array}{l}\text { Sci.-Mater. } \\
\text { Med }\end{array}$ & 16 & $\begin{array}{l}\text { Materials } \\
\text { science, Bio- } \\
\text { materials }\end{array}$ & Q3 & 2.448 & $2.17 \%$ \\
\hline
\end{tabular}

\subsubsection{Author analysis}

Table 6 shows the 10 authors with the most occurrences and the 10 most cited authors. Among all the authors, the two most prominent are Dong-Woo Cho and Ali Khademhosseini. In addition to being the authors with more articles published about AM technologies for biomedical applications, they were also the most cited.

\subsubsection{Research area analysis}

According to the categories of the Web of Science, in all cases, as expected, articles studied were in the "Engineering, Biomedical" category, but in most cases, also in the "Materials Science, Biomaterials" category (see figure 5). In the case of cited documents, i.e. in the case of the knowledge used, the two predominant areas were the same (see figure 6). Therefore, the importance of Materials Sciences and Biomaterials for that field was noted.

The institution that has published the most articles about AM technologies for biomedical engineering applications is the Massachusetts Institute of Technology (36 articles) and the institution that has been the most cited is Harvard University (72 articles) 
Table 6. The 10 authors with the most occurrences and the 10 most cited authors

\begin{tabular}{|c|c|c|c|c|c|c|c|c|c|c|}
\hline \multicolumn{6}{|c|}{$\begin{array}{l}\text { Research carried out in AM for BE } \\
\text { (Who researching is) }\end{array}$} & \multicolumn{5}{|c|}{$\begin{array}{l}\text { Research used to develop research in AM for BE } \\
\text { (Who knowledge comes from) }\end{array}$} \\
\hline$\#$ & Author & $h$-index* & $\begin{array}{c}\text { \# of } \\
\text { articles }\end{array}$ & $\begin{array}{c}\% \text { of } \\
\text { articles }\end{array}$ & $\begin{array}{l}\text { Share of pu- } \\
\text { blications* }\end{array}$ & $\#$ & Cited author & $h$-index* & $\begin{array}{l}\text { \# of } \\
\text { times } \\
\text { cited }\end{array}$ & $\begin{array}{l}\% \text { of } \\
\text { cites }\end{array}$ \\
\hline 1 & Cho, Dong-Woo & 37 & 35 & $2.86 \%$ & $254 / 35$ & 1 & Khademhosseini, Ali & 91 & 24 & $3.26 \%$ \\
\hline 2 & Khademhosseini, Ali & 91 & 19 & $1.55 \%$ & $597 / 19$ & 2 & Cho, Dong-Woo & 37 & 23 & $3.12 \%$ \\
\hline 3 & Moroni, Lorenzo & 26 & 16 & $1.31 \%$ & $133 / 16$ & 3 & Langer, Robert & 184 & 21 & $2.85 \%$ \\
\hline 4 & Mano, Joao F & 58 & 13 & $1.06 \%$ & $395 / 13$ & 4 & Picart, Catherine & 40 & 19 & $2.58 \%$ \\
\hline 5 & Shim, Jin-Hyung & 19 & 13 & 1.06 & $54 / 13$ & 5 & Dhert, Wouter J. A & 44 & 16 & $2.17 \%$ \\
\hline 6 & Fischer, Horst & 33 & 12 & $0.98 \%$ & $176 / 12$ & 6 & Mikos, AG & 109 & 16 & $2.17 \%$ \\
\hline 7 & Gbureck, Uwe & 39 & 12 & $0.98 \%$ & $122 / 12$ & 7 & $\begin{array}{l}\text { Hutmacher, Dietmar } \\
\text { Werner }\end{array}$ & 21 & 15 & $2.04 \%$ \\
\hline 8 & Hollister, Scott J & 40 & 12 & $0.98 \%$ & $118 / 12$ & 8 & Sun, Wei & 105 & 15 & $2.04 \%$ \\
\hline 9 & $\begin{array}{l}\text { Hutmacher, Dietmar } \\
\text { Werner }\end{array}$ & 21 & 12 & $0.98 \%$ & $43 / 12$ & 9 & Voegel, JC & 68 & 15 & $2.04 \%$ \\
\hline 10 & Reis, Rui L & 66 & 12 & $0.98 \%$ & $692 / 12$ & 10 & Malda, Jos & 32 & 14 & $1.90 \%$ \\
\hline
\end{tabular}

*Data obtained on November $3^{\text {th }}, 2018$

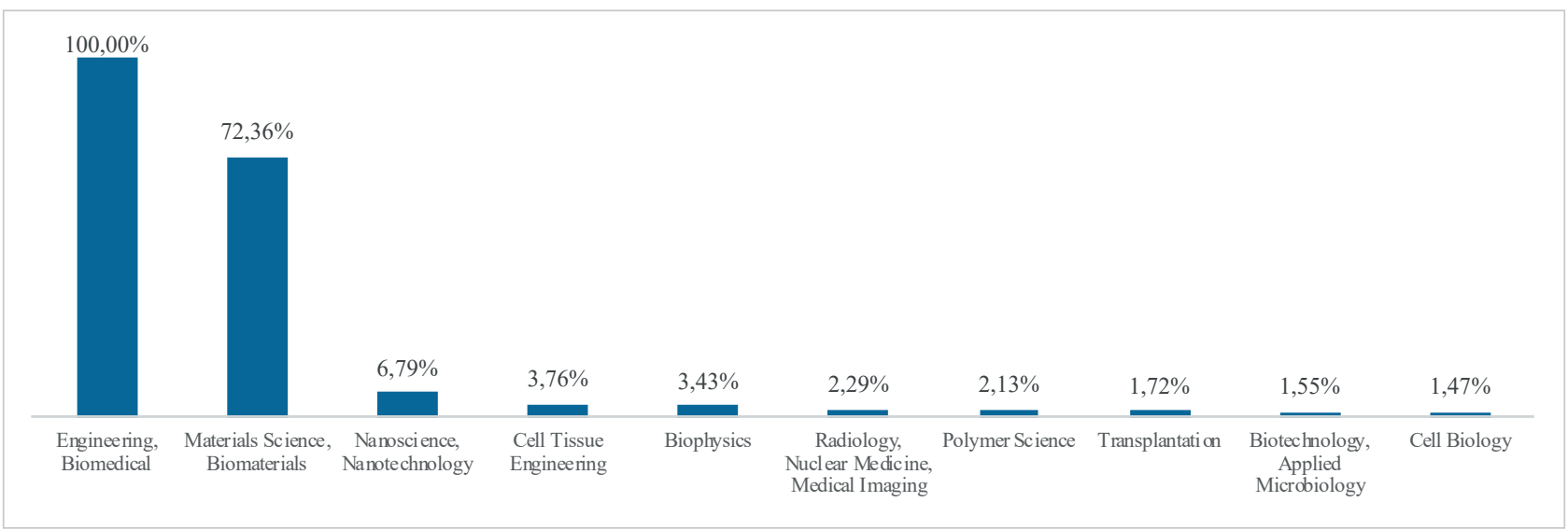

Figure 5. The 10 most frequent research areas in AM technologies for BE application articles

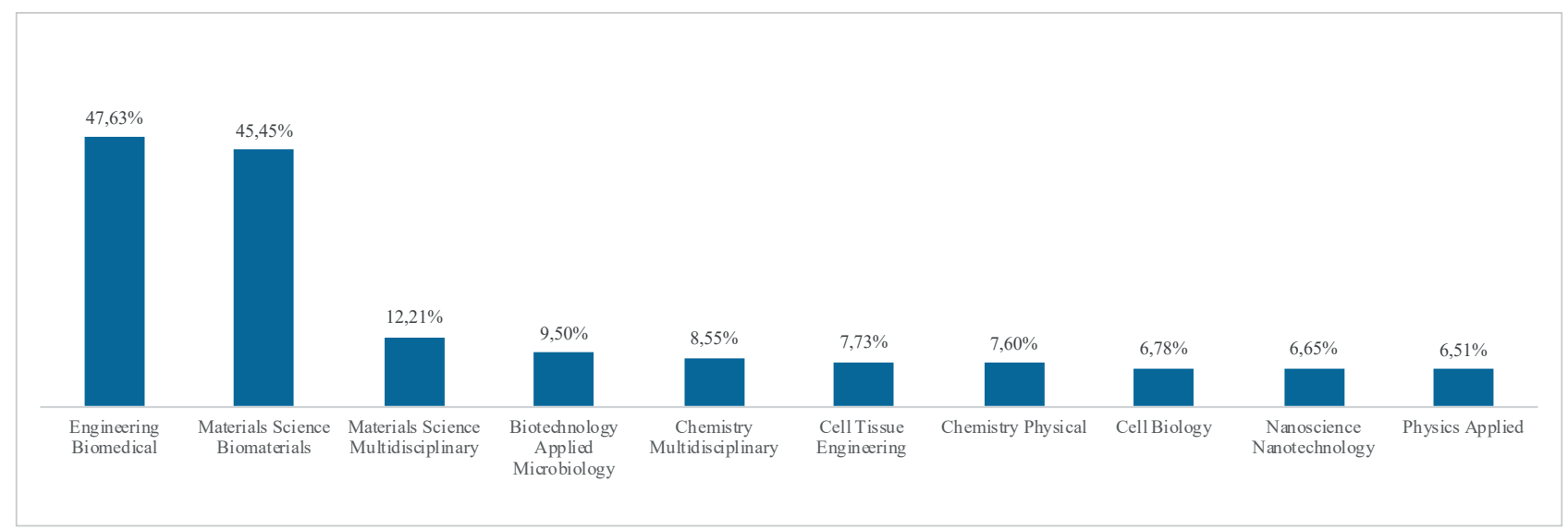

Figure 6. The 10 most frequent research areas in references used for AM technologies for BE application articles

\subsubsection{Keyword analysis}

The distance-based graph allows us to define the relationship forces of items, i.e., the closer they are the stronger their relationship. With regard to mapping keywords relating to the articles under study, the main hotspots that have a strong relationship between them are, on the one hand, "3D print" "Scaffold" "Additive manufacturing" "bone" and "rapid prototype", along with "Tissue Engineering", "3D bioprinter" and "hydrogel", and on the other hand, "layer by layer" and "alginate" (see figure 7). 


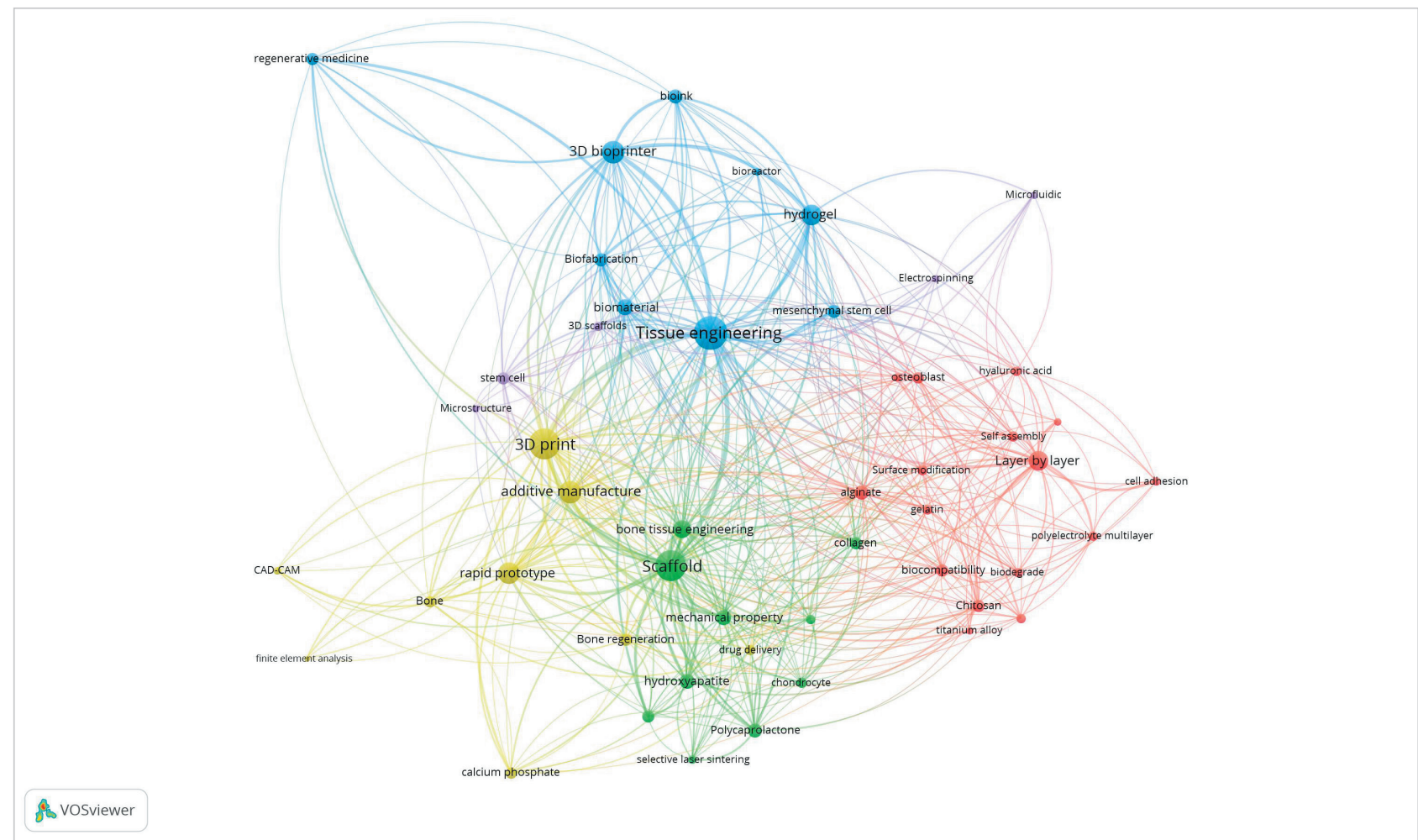

Figure 7. The top 50 keywords in AM technologies for BE application articles

As far as mapping keywords of the cited articles is concerned, the main points of knowledge are linked to "scaffold", "bone", "bone tissue engineering", "rapid prototype", "3D print" and "hydroxyapatite", and conversely "tissue engineering", "biomaterial", "hydrogel" and "bioprinter" (see figure 8).

The clustering process carried out on the map of study articles defines 5 clusters, the terms of which allow us to define the following research fields: "Tissue engineering and bioprinting", "Scaffold and bone tissue engineering", "3D print and rapid prototyping", "layer by layer - surface modification - alginate" and "microstructure and stem cell". Regarding the clusters defined in the keyword map of the cited articles, there are also 5 clusters that define the following research

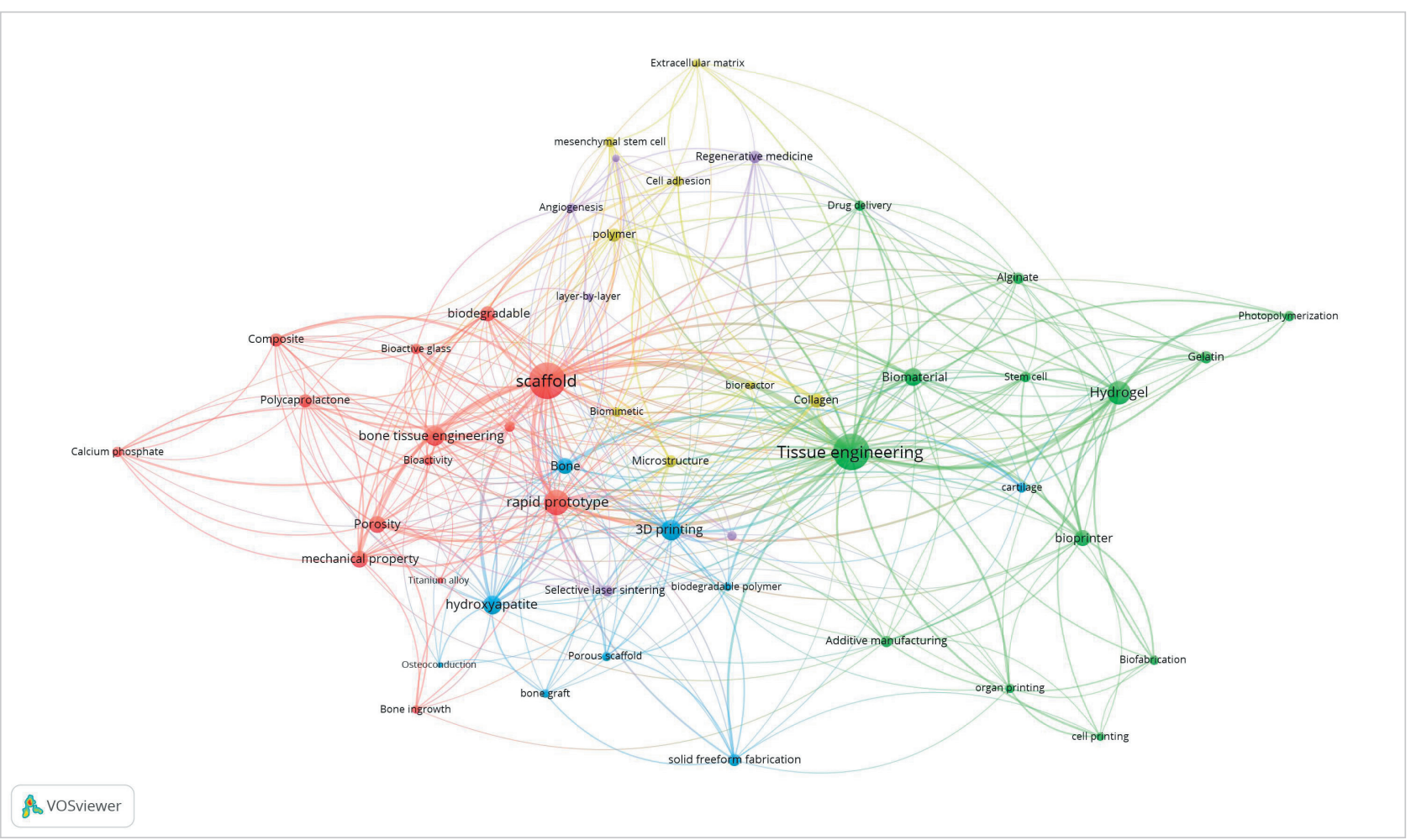

Figure 8. The top 50 keywords in references used for AM technologies for BE application articles 
areas: "Scaffold and bone tissue engineering", "Tissue engineering and bioprinting", "3D print and bone", "Biomimetic and microstructure" and "Regenerative medicine".

\subsection{Research impact}

In this section, in order to appreciate the impact of these technologies, the impact that scientific publications had was determined from the results obtained from different impact indicator analyses. Moreover, the research impact measured and analyzed was varied: academic impact (from citation counts, Mendeley readers, and Wikipedia citations), and industrial and commercial impact (from Google Patents citations).

In addition, with the USA and China the countries with more publications in the field of study, the behavior of the impact of the research carried out by these countries was analyzed.

Tables 5 and table 6 contain the arithmetic mean, the geometric mean, the arithmetic mean of the log-transformed of the indicators analyzed, and the proportion of articles with at least one measure. In addition, where possible, 95\% confidence intervals are given. They also contain the Mean Normalized Log-transformed Citation Scores $(\text { MNLCS })^{2}$ and the Normalized Proportion Cited (EMNPC) ${ }^{3}$ with confidence intervals, where possible.

\subsubsection{Academic impact}

\section{Citation counts}

First, it can be seen that the most cited articles, in general, are those that have been published earlier, i.e., those that have had the longest time to be cited (see table 7).

From the results obtained, it is observed that, on the one hand, practically all articles are cited at least once; and on the other hand, in general, the USA is cited above the world average, however, this does not occur with China.

For articles published from 2006 to 2015, the MNLCS values are higher than 1 for the USA, which indicates that the citation counts for the USA tend to be above the world average. However, for articles published in 2014 the confidence interval does not contain 1 so only in that case is the difference statistically significant, for the rest of the years the difference is not statistically significant. In the case of China, it is observed that, in general, Chinese articles are cited below the world average.

Finally, for articles published in the decade analyzed, when the non-zero proportion is not 1 for the World, the USA and China are above the world average for the proportion cited (except in the case of 2013 for the USA, and 2013 and 2015 for China), i.e. EMNPC values are higher than 1.

\section{Mendeley reader counts}

Mendeley readership counts are useful indicators of academic impact and they can provide earlier evidence of impact than citations might (Thelwall, 2016; Aduku; Thelwall; Kousha, 2017).

In this case, the most read articles, in general, are not those that have been published earlier, i.e., there is no relation between the publication date and number of readers (see table 8 ).

Practically all articles have been gathered by Mendeley users. Likewise, it is observed that practically all articles analyzed from the USA and China have been gathered in Mendeley at least once.

Finally, the articles from USA are more read than the world average. The MNLCS value is higher than 1 for all analyzed years. Nevertheless, the same does not occur in the case of China, i.e. the research analyzed from China is less read than the world average, in general.

\section{Wikipedia citation counts}

Wikipedia citations are a useful new source of evidence for scholarly impact; however, citations from the online encyclopaedia to academic studies may reflect the value of research for a more general public or education (Thelwall; Kousha, 2015a; Kousha; Thelwall, 2017a; Thelwall, 2018; Thelwall; Sud, 2018). Nonetheless, in this case, it is observed that practically no articles of the study were cited on Wikipedia (see table 9). The proportion of articles with at least 1 Wikipedia citation was a maximum of $3.6 \%$ in 2010 . Moreover, no Chinese article were mentioned on Wikipedia.

\subsubsection{Industrial and commercial impact}

\section{Google Patents citation counts}

Citations from patents to scientific articles could be used to assess the commercial value or technological benefits of the cited studies (Thelwall; Kousha, 2015a; Thelwall, 2018).

In this case, it can be observed that the most cited articles in patents, in general, are those that have been published earlier, i.e., those that have had the longest time to be cited (see table 10).

In this case, both countries, the USA and China, in general, are cited above the world average and their non-zero proportion is also above world average. 
Table 7. Academic impact of AM technologies for biomedical engineering applications

\begin{tabular}{|c|c|c|c|c|}
\hline \multicolumn{5}{|c|}{ Academic impact } \\
\hline \multicolumn{5}{|c|}{ - Citation counts for individual sets of articles - } \\
\hline Indicators & Year & World & USA & China \\
\hline \multirow{10}{*}{$\begin{array}{l}\text { Arithmetic } \\
\text { mean of raw } \\
\text { data }\end{array}$} & 2006 & 84.032258 & 99.875000 & 103.000000 \\
\hline & 2007 & 68.187500 & 84.666667 & 66.000000 \\
\hline & 2008 & 50.695652 & 52.333333 & 34.600000 \\
\hline & 2009 & 64.578125 & 113.105263 & 51.571429 \\
\hline & 2010 & 61.107143 & 85.272727 & 55.571429 \\
\hline & 2011 & 43.296875 & 51.608696 & 43.750000 \\
\hline & 2012 & 35.409091 & 46.217391 & 35.250000 \\
\hline & 2013 & 34.820000 & 52.562500 & 24.437500 \\
\hline & 2014 & 37.425926 & 50.285714 & 31.600000 \\
\hline & 2015 & 23.411392 & 22.105263 & 21.148148 \\
\hline \multirow{10}{*}{$\begin{array}{l}\text { Geometric } \\
\text { mean }(95 \% \mathrm{Cl}) \\
\text { of raw data }\end{array}$} & 2006 & $61.403058(44.368132,84.834296)$ & $84.802648(61.030532,117.685010)$ & $99.969791(62.821825,158.740005)$ \\
\hline & 2007 & $42.739649(27.909845,65.176656)$ & $58.212670(27.134051,123.622657)$ & $54.181519(-0.984488,196295.414710)$ \\
\hline & 2008 & $28.461897(19.646144,41.041910)$ & $42.873627(25.735862,70.996747)$ & $23.936505(4.537577,111.292673)$ \\
\hline & 2009 & $36.162970(27.451244,47.542211)$ & $48.330852(23.943112,96.563326)$ & $34.758256(18.500242,64.571129)$ \\
\hline & 2010 & $36.551322(28.126404,47.413178)$ & $44.843045(27.646500,72.362708)$ & $39.525709(16.090030,95.098899)$ \\
\hline & 2011 & $26.276796(19.647951,35.033773)$ & $34.471750(21.387664,55.202606)$ & $25.409614(8.995830,68.775868)$ \\
\hline & 2012 & $21.793240(16.800286,28.186710)$ & $24.017256(14.035283,40.626294)$ & $22.547858(11.089531,44.866266)$ \\
\hline & 2013 & $20.175256(16.189655,25.084959)$ & $24.344006(14.872179,39.468207)$ & $14.203120(7.239744,27.051219)$ \\
\hline & 2014 & $21.611618(17.404608,26.780287)$ & $32.456863(22.840587,45.951934)$ & $17.450977(10.001326,29.945229)$ \\
\hline & 2015 & $13.139339(10.865472,15.848963)$ & $13.469733(9.939594,18.139025)$ & $12.722162(7.928466,20.089597)$ \\
\hline \multirow{10}{*}{$\begin{array}{l}\text { Mean }(95 \% \mathrm{Cl}) \\
\text { of } \ln (1+\text { raw } \\
\text { data })\end{array}$} & 2006 & $4.133614(3.814810,4.452419)$ & $4.452050(4.127627,4.776473)$ & $4.614821(4.156095,5.073548)$ \\
\hline & 2007 & $3.778255(3.364182,4.192328)$ & $4.081136(3.336981,4.825290)$ & $4.010628(-4.166125,12.187381)$ \\
\hline & 2008 & $3.383098(3.027529,3.738667)$ & $3.781313(3.286006,4.276621)$ & $3.216333(1.711557,4.721109)$ \\
\hline & 2009 & $3.615313(3.348192,3.882434)$ & $3.898550(3.216598,4.580502)$ & $3.576781(2.970427,4.183135)$ \\
\hline & 2010 & $3.625709(3.371645,3.879772)$ & $3.825224(3.355031,4.295416)$ & $3.701937(2.838495,4.565378)$ \\
\hline & 2011 & $3.306036(3.027616,3.584457)$ & $3.568737(3.108510,4.028963)$ & $3.273728(2.302168,4.245288)$ \\
\hline & 2012 & $3.126464(2.879215,3.373713)$ & $3.219566(2.710400,3.728732)$ & $3.159035(2.492340,3.825730)$ \\
\hline & 2013 & $3.052833(2.844308,3.261359)$ & $3.232542(2.764568,3.700517)$ & $2.721501(2.108969,3.334032)$ \\
\hline & 2014 & $3.118464(2.912601,3.324327)$ & $3.510257(3.171389,3.849124)$ & $2.915117(2.398016,3.432219)$ \\
\hline & 2015 & $2.648961(2.473633,2.824289)$ & $2.672059(2.392389,2.951729)$ & $2.619012(2.189245,3.048780)$ \\
\hline \multirow{10}{*}{$\begin{array}{l}\text { Proportion } \\
(95 \% \mathrm{CI}) \\
\text { non-zero }\end{array}$} & 2006 & $1.000000(0.889745,1.000000)$ & $1.000000(0.806392,1.000000)$ & $1.000000(0.510109,1.000000)$ \\
\hline & 2007 & $0.968750(0.842557,0.994462)$ & $1.000000(0.700855,1.000000)$ & $1.000000(0.342380,1.000000)$ \\
\hline & 2008 & $0.978261(0.886647,0.996152)$ & $1.000000(0.700855,1.000000)$ & $1.000000(0.565518,1.000000)$ \\
\hline & 2009 & $1.000000(0.943376,1.000000)$ & $1.000000(0.831821,1.000000)$ & $1.000000(0.784689,1.000000)$ \\
\hline & 2010 & $1.000000(0.935806,1.000000)$ & $1.000000(0.851345,1.000000)$ & $1.000000(0.645670,1.000000)$ \\
\hline & 2011 & $0.984375(0.916659,0.997236)$ & $1.000000(0.856883,1.000000)$ & $1.000000(0.675592,1.000000)$ \\
\hline & 2012 & $1.000000(0.944997,1.000000)$ & $1.000000(0.856883,1.000000)$ & $1.000000(0.757506,1.000000)$ \\
\hline & 2013 & $0.980000(0.929988,0.994498)$ & $0.968750(0.842557,0.994462)$ & $0.937500(0.716713,0.988881)$ \\
\hline & 2014 & $0.990741(0.949407,0.998364)$ & $1.000000(0.901099,1.000000)$ & $1.000000(0.838875,1.000000)$ \\
\hline & 2015 & $0.968354(0.928067,0.986409)$ & $0.982456(0.907093,0.996896)$ & $0.962963(0.817165,0.993432)$ \\
\hline \multirow{10}{*}{$\begin{array}{l}\text { MNLCS - mean } \\
(95 \% \mathrm{CI}) \text { of } \\
\text { world norma- } \\
\text { lized In( } 1+\text { raw } \\
\text { data) }\end{array}$} & 2006 & $1.000000(0.898357,1.113144)$ & $1.077036(0.971920,1.194788)$ & $1.116413(1.010838,1.235349)$ \\
\hline & 2007 & $1.000000(0.858399,1.164959)$ & $1.080164(0.881215,1.305376)$ & $1.061503(0.705643,1.443172)$ \\
\hline & 2008 & $1.000000(0.862575,1.159320)$ & $1.117707(0.955024,1.305360)$ & $0.950706(0.620988,1.301663)$ \\
\hline & 2009 & $1.000000(0.901516,1.109242)$ & $1.078344(0.887113,1.281412)$ & $0.989342(0.822578,1.166968)$ \\
\hline & 2010 & $1.000000(0.906364,1.103309)$ & $1.055028(0.915100,1.205161)$ & $1.021024(0.818497,1.233429)$ \\
\hline & 2011 & $1.000000(0.888473,1.125527)$ & $1.079461(0.924069,1.250273)$ & $0.990227(0.734631,1.259970)$ \\
\hline & 2012 & $1.000000(0.894934,1.117401)$ & $1.029779(0.858410,1.214109)$ & $1.010418(0.806342,1.227211)$ \\
\hline & 2013 & $1.000000(0.908632,1.100556)$ & $1.058866(0.898164,1.229297)$ & $0.891467(0.697145,1.094147)$ \\
\hline & 2014 & $1.000000(0.911568,1.097011)$ & $1.125637(1.001509,1.259421)$ & $0.934793(0.769841,1.107764)$ \\
\hline & 2015 & $1.000000(0.910488,1.098312)$ & $1.008720(0.889653,1.136663)$ & $0.988694(0.823503,1.162586)$ \\
\hline \multirow{10}{*}{$\begin{array}{l}\text { EMNPC (NPC) - } \\
\text { world normali- } \\
\text { zed proportion } \\
(95 \% \mathrm{CI}) \text { cited } \\
\text { (non-zero) }\end{array}$} & 2006 & $1.000000\left(\mathrm{NaN}^{4}, \mathrm{NaN}\right)$ & $1.000000(\mathrm{NaN}, \mathrm{NaN})$ & $1.000000(\mathrm{NaN}, \mathrm{NaN})$ \\
\hline & 2007 & $1.000000(0.940134,1.063678)$ & $1.032258(\mathrm{NaN}, \mathrm{NaN})$ & $1.032258(\mathrm{NaN}, \mathrm{NaN})$ \\
\hline & 2008 & $1.000000(0.958063,1.043772)$ & $1.022222(\mathrm{NaN}, \mathrm{NaN})$ & $1.022222(\mathrm{NaN}, \mathrm{NaN})$ \\
\hline & 2009 & $1.000000(\mathrm{NaN}, \mathrm{NaN})$ & $1.000000(\mathrm{NaN}, \mathrm{NaN})$ & $1.000000(\mathrm{NaN}, \mathrm{NaN})$ \\
\hline & 2010 & $1.000000(\mathrm{NaN}, \mathrm{NaN})$ & $1.000000(\mathrm{NaN}, \mathrm{NaN})$ & $1.000000(\mathrm{NaN}, \mathrm{NaN})$ \\
\hline & 2011 & $1.000000(0.969723,1.031222)$ & $1.015873(\mathrm{NaN}, \mathrm{NaN})$ & $1.015873(\mathrm{NaN}, \mathrm{NaN})$ \\
\hline & 2012 & $1.000000(\mathrm{NaN}, \mathrm{NaN})$ & $1.000000(\mathrm{NaN}, \mathrm{NaN})$ & $1.000000(\mathrm{NaN}, \mathrm{NaN})$ \\
\hline & 2013 & $1.000000(0.966373,1.034797)$ & $0.988520(0.940399,1.039104)$ & $0.956633(0.873188,1.048051)$ \\
\hline & 2014 & $1.000000(0.981974,1.018356)$ & $1.009346(\mathrm{NaN}, \mathrm{NaN})$ & $1.009346(\mathrm{NaN}, \mathrm{NaN})$ \\
\hline & 2015 & $1.000000(0.962948,1.038478)$ & $1.014563(0.978509,1.051944)$ & $0.994432(0.938128,1.054116)$ \\
\hline
\end{tabular}


Table 8. Mendeley reader counts of AM technologies for biomedical engineering applications

\begin{tabular}{|c|c|c|c|c|}
\hline \multicolumn{5}{|c|}{ - Mendeley reader counts - } \\
\hline Indicators & Year & World & USA & China \\
\hline \multirow{10}{*}{$\begin{array}{l}\text { Arithmetic } \\
\text { mean of raw } \\
\text { data }\end{array}$} & 2006 & 80.322581 & 105.375000 & 84.750000 \\
\hline & 2007 & 63.187500 & 112.222222 & 80.500000 \\
\hline & 2008 & 56.782609 & 80.666667 & 30.400000 \\
\hline & 2009 & 79.468750 & 169.105263 & 42.785714 \\
\hline & 2010 & 85.464286 & 127.454545 & 48.428571 \\
\hline & 2011 & 67.062500 & 82.913043 & 72.375000 \\
\hline & 2012 & 61.439394 & 96.260870 & 56.750000 \\
\hline & 2013 & 71.140000 & 114.968750 & 29.687500 \\
\hline & 2014 & 86.990741 & 131.142857 & 64.500000 \\
\hline & 2015 & 63.829114 & 63.105263 & 51.962963 \\
\hline \multirow{10}{*}{$\begin{array}{l}\text { Geometric mean } \\
(95 \% \mathrm{Cl}) \text { of raw } \\
\text { data }\end{array}$} & 2006 & $42.858398(25.962429,70.342202)$ & $65.098589(31.233380,134.543449)$ & $70.485395(22.480137,216.637640)$ \\
\hline & 2007 & $40.531585(26.858925,60.914540)$ & $66.312377(27.517542,157.883125)$ & $54.695601(-0.999584,7464696.637597)$ \\
\hline & 2008 & $26.393798(17.042271,40.592335)$ & $60.056535(31.823396,112.574491)$ & $23.500815(7.141632,72.730911)$ \\
\hline & 2009 & $41.128847(32.140176,52.555532)$ & $71.156707(38.024113,132.419825)$ & $31.957020(19.720930,51.418747)$ \\
\hline & 2010 & $47.286862(35.912207,62.166666)$ & $64.483888(39.317602,105.358994)$ & $41.708099(23.280220,74.122123)$ \\
\hline & 2011 & $39.875029(29.617857,53.568415)$ & $53.910422(35.071271,82.588804)$ & $36.177941(14.146939,90.252718)$ \\
\hline & 2012 & $34.760151(26.584395,45.359123)$ & $41.650246(22.265398,77.186646)$ & $28.227489(13.784274,56.780729)$ \\
\hline & 2013 & $36.569170(28.651956,46.600318)$ & $52.448148(33.476166,81.860273)$ & $20.445194(11.902626,34.643623)$ \\
\hline & 2014 & $47.498319(37.409307,60.237423)$ & $78.744293(51.824747,119.382069)$ & $33.471535(18.921628,58.648074)$ \\
\hline & 2015 & $39.345145(33.151499,46.662059)$ & $43.719463(34.858349,54.770285)$ & $35.861180(23.250475,55.029691)$ \\
\hline \multirow{10}{*}{$\begin{array}{l}\text { Mean }(95 \% \mathrm{Cl}) \text { of } \\
\text { In(1+raw data) }\end{array}$} & 2006 & $3.780966(3.294444,4.267488)$ & $4.191147(3.473003,4.909292)$ & $4.269493(3.156155,5.382831)$ \\
\hline & 2007 & $3.726454(3.327153,4.125755)$ & $4.209344(3.350519,5.068169)$ & $4.019901(-7.785893,15.825695)$ \\
\hline & 2008 & $3.310317(2.892717,3.727916)$ & $4.111800(3.491142,4.732459)$ & $3.198706(2.096991,4.300422)$ \\
\hline & 2009 & $3.740733(3.500746,3.980719)$ & $4.278840(3.664180,4.893501)$ & $3.495204(3.031144,3.959264)$ \\
\hline & 2010 & $3.877160(3.608542,4.145777)$ & $4.181804(3.696788,4.666820)$ & $3.754389(3.189662,4.319115)$ \\
\hline & 2011 & $3.710519(3.421583,3.999455)$ & $4.005703(3.585497,4.425910)$ & $3.615716(2.717798,4.513633)$ \\
\hline & 2012 & $3.576834(3.317250,3.836418)$ & $3.753033(3.146967,4.359099)$ & $3.375110(2.693564,4.056655)$ \\
\hline & 2013 & $3.626184(3.389528,3.862839)$ & $3.978712(3.540268,4.417156)$ & $3.065501(2.557431,3.573570)$ \\
\hline & 2014 & $3.881529(3.648300,4.114758)$ & $4.378825(3.966980,4.790671)$ & $3.540134(2.991806,4.088462)$ \\
\hline & 2015 & $3.697471(3.530806,3.864136)$ & $3.800409(3.579576,4.021241)$ & $3.607159(3.188436,4.025882)$ \\
\hline \multirow{10}{*}{$\begin{array}{l}\text { Proportion } \\
(95 \% \mathrm{Cl}) \\
\text { non-zero }\end{array}$} & 2006 & $0.967742(0.838059,0.994283)$ & $0.937500(0.716713,0.988881)$ & $1.000000(0.510109,1.000000)$ \\
\hline & 2007 & $0.968750(0.842557,0.994462)$ & $1.000000(0.700855,1.000000)$ & $1.000000(0.342380,1.000000)$ \\
\hline & 2008 & $0.934783(0.824973,0.977572)$ & $1.000000(0.700855,1.000000)$ & $1.000000(0.565518,1.000000)$ \\
\hline & 2009 & $1.000000(0.943376,1.000000)$ & $1.000000(0.831821,1.000000)$ & $1.000000(0.784689,1.000000)$ \\
\hline & 2010 & $1.000000(0.935806,1.000000)$ & $1.000000(0.851345,1.000000)$ & $1.000000(0.645670,1.000000)$ \\
\hline & 2011 & $0.968750(0.893027,0.991388)$ & $1.000000(0.856883,1.000000)$ & $1.000000(0.675592,1.000000)$ \\
\hline & 2012 & $0.984848(0.919041,0.997320)$ & $0.956522(0.790088,0.992283)$ & $1.000000(0.757506,1.000000)$ \\
\hline & 2013 & $0.970000(0.915481,0.989745)$ & $1.000000(0.892821,1.000000)$ & $1.000000(0.806392,1.000000)$ \\
\hline & 2014 & $0.972222(0.921497,0.990509)$ & $0.971429(0.854669,0.994939)$ & $1.000000(0.838875,1.000000)$ \\
\hline & 2015 & $0.981013(0.945669,0.993522)$ & $1.000000(0.936861,1.000000)$ & $0.962963(0.817165,0.993432)$ \\
\hline \multirow{10}{*}{$\begin{array}{l}\text { MNLCS - mean } \\
(95 \% \mathrm{CI}) \text { of } \\
\text { world norma- } \\
\text { lized In }(1+\text { raw } \\
\text { data) }\end{array}$} & 2006 & $1.000000(0.835602,1.196743)$ & $1.108486(0.895276,1.358281)$ & $1.129207(0.907152,1.389285)$ \\
\hline & 2007 & $1.000000(0.861350,1.160968)$ & $1.129584(0.904172,1.381237)$ & $1.078747(0.566643,1.615911)$ \\
\hline & 2008 & $1.000000(0.837112,1.194584)$ & $1.242117(1.032706,1.491702)$ & $0.966284(0.708469,1.255351)$ \\
\hline & 2009 & $1.000000(0.913956,1.094145)$ & $1.143851(0.975314,1.321842)$ & $0.934364(0.808333,1.068117)$ \\
\hline & 2010 & $1.000000(0.907374,1.102081)$ & $1.078574(0.942031,1.225315)$ & $0.968335(0.836317,1.109509)$ \\
\hline & 2011 & $1.000000(0.896467,1.115490)$ & $1.079553(0.947580,1.224698)$ & $0.974450(0.761796,1.198994)$ \\
\hline & 2012 & $1.000000(0.903185,1.107193)$ & $1.049261(0.873699,1.235935)$ & $0.943603(0.761772,1.135425)$ \\
\hline & 2013 & $1.000000(0.912532,1.095852)$ & $1.097217(0.964348,1.239286)$ & $0.845379(0.705984,0.992006)$ \\
\hline & 2014 & $1.000000(0.919201,1.087901)$ & $1.128119(1.008923,1.255326)$ & $0.912046(0.770583,1.059987)$ \\
\hline & 2015 & $1.000000(0.938192,1.065879)$ & $1.027840(0.955170,1.104695)$ & $0.975575(0.860030,1.095092)$ \\
\hline \multirow{10}{*}{$\begin{array}{l}\text { EMNPC (NPC) - } \\
\text { world normali- } \\
\text { zed proportion } \\
(95 \% \mathrm{Cl}) \text { cited } \\
\text { (non-zero) }\end{array}$} & 2006 & $1.000000(0.938248,1.065816)$ & $0.968750(0.877548,1.069431)$ & 1.033333 ( $\mathrm{NaN}, \mathrm{NaN})$ \\
\hline & 2007 & $1.000000(0.940134,1.063678)$ & $1.032258(\mathrm{NaN}, \mathrm{NaN})$ & $1.032258(\mathrm{NaN}, \mathrm{NaN})$ \\
\hline & 2008 & $1.000000(0.906673,1.102934)$ & $1.069767(\mathrm{NaN}, \mathrm{NaN})$ & $1.069767(\mathrm{NaN}, \mathrm{NaN})$ \\
\hline & 2009 & $1.000000(\mathrm{NaN}, \mathrm{NaN})$ & $1.000000(\mathrm{NaN}, \mathrm{NaN})$ & $1.000000(\mathrm{NaN}, \mathrm{NaN})$ \\
\hline & 2010 & $1.000000(\mathrm{NaN}, \mathrm{NaN})$ & $1.000000(\mathrm{NaN}, \mathrm{NaN})$ & $1.000000(\mathrm{NaN}, \mathrm{NaN})$ \\
\hline & 2011 & $1.000000(0.947739,1.055142)$ & $1.032258(\mathrm{NaN}, \mathrm{NaN})$ & $1.032258(\mathrm{NaN}, \mathrm{NaN})$ \\
\hline & 2012 & $1.000000(0.970630,1.030258)$ & $0.971237(0.910601,1.035911)$ & $1.015385(\mathrm{NaN}, \mathrm{NaN})$ \\
\hline & 2013 & $1.000000(0.956586,1.045384)$ & $1.030928(\mathrm{NaN}, \mathrm{NaN})$ & $1.030928(\mathrm{NaN}, \mathrm{NaN})$ \\
\hline & 2014 & $1.000000(0.959774,1.041912)$ & $0.999184(0.951089,1.049710)$ & $1.028571(\mathrm{NaN}, \mathrm{NaN})$ \\
\hline & 2015 & $1.000000(0.972427,1.028355)$ & $1.019355(\mathrm{NaN}, \mathrm{NaN})$ & $0.981601(0.928647,1.037574)$ \\
\hline
\end{tabular}


Table 9. Wikipedia citations counts of AM technologies for biomedical engineering applications

\begin{tabular}{|c|c|c|c|c|}
\hline \multicolumn{5}{|c|}{ - Wikipedia citations counts - } \\
\hline Indicators & Year & World & USA & China \\
\hline \multirow{10}{*}{$\begin{array}{l}\text { Arithmetic mean } \\
\text { (unique URLs }{ }^{5} \text { ) }\end{array}$} & 2006 & 0.032258 & 0.000000 & 0.000000 \\
\hline & 2007 & 0.000000 & 0.000000 & 0.000000 \\
\hline & 2008 & 0.000000 & 0.000000 & 0.000000 \\
\hline & 2009 & 0.015625 & 0.052632 & 0.000000 \\
\hline & 2010 & 0.035714 & 0.045455 & 0.000000 \\
\hline & 2011 & 0.015625 & 0.043478 & 0.000000 \\
\hline & 2012 & 0.045455 & 0.130435 & 0.000000 \\
\hline & 2013 & 0.020000 & 0.031250 & 0.000000 \\
\hline & 2014 & 0.000000 & 0.000000 & 0.000000 \\
\hline & 2015 & 0.012658 & 0.035088 & 0.000000 \\
\hline \multirow{10}{*}{$\begin{array}{l}\text { Geometric mean } \\
(95 \% \mathrm{CI}) \text { of unique } \\
\text { URLs }\end{array}$} & 2006 & $0.022611(-0.022986,0.070337)$ & $0.000000(0.000000,0.000000)$ & $0.000000(0.000000,0.000000)$ \\
\hline & 2007 & $0.000000(0.000000,0.000000)$ & $0.000000(0.000000,0.000000)$ & $0.000000(0.000000,0.000000)$ \\
\hline & 2008 & $0.000000(0.000000,0.000000)$ & $0.000000(0.000000,0.000000)$ & $0.000000(0.000000,0.000000)$ \\
\hline & 2009 & $0.010889(-0.010772,0.033025)$ & $0.037155(-0.039335,0.119735)$ & $0.000000(0.000000,0.000000)$ \\
\hline & 2010 & $0.025064(-0.010228,0.061615)$ & $0.032008(-0.033455,0.101905)$ & $0.000000(0.000000,0.000000)$ \\
\hline & 2011 & $0.010889(-0.010772,0.033025)$ & $0.030596(-0.031732,0.096935)$ & $0.000000(0.000000,0.000000)$ \\
\hline & 2012 & $0.021227(-0.020785,0.065041)$ & $0.062127(-0.062457,0.203267)$ & $0.000000(0.000000,0.000000)$ \\
\hline & 2013 & $0.013959(-0.005627,0.033932)$ & $0.021897(-0.022275,0.068065)$ & $0.000000(0.000000,0.000000)$ \\
\hline & 2014 & $0.000000(0.000000,0.000000)$ & $0.000000(0.000000,0.000000)$ & $0.000000(0.000000,0.000000)$ \\
\hline & 2015 & $0.008813(-0.003465,0.021242)$ & $0.024619(-0.010056,0.060508)$ & $0.000000(0.000000,0.000000)$ \\
\hline \multirow{10}{*}{$\begin{array}{l}\text { Mean }(95 \% \mathrm{Cl}) \text { of } \\
\text { log }(1+\text { unique } \\
\text { URLs) }\end{array}$} & 2006 & $0.022360(-0.023254,0.067973)$ & $0.000000(0.000000,0.000000)$ & $0.000000(0.000000,0.000000)$ \\
\hline & 2007 & $0.000000(0.000000,0.000000)$ & $0.000000(0.000000,0.000000)$ & $0.000000(0.000000,0.000000)$ \\
\hline & 2008 & $0.000000(0.000000,0.000000)$ & $0.000000(0.000000,0.000000)$ & $0.000000(0.000000,0.000000)$ \\
\hline & 2009 & $0.010830(-0.010830,0.032491)$ & $0.036481(-0.040130,0.113092)$ & $0.000000(0.000000,0.000000)$ \\
\hline & 2010 & $0.024755(-0.010281,0.059792)$ & $0.031507(-0.034027,0.097041)$ & $0.000000(0.000000,0.000000)$ \\
\hline & 2011 & $0.010830(-0.010830,0.032491)$ & $0.030137(-0.032246,0.092520)$ & $0.000000(0.000000,0.000000)$ \\
\hline & 2012 & $0.021004(-0.021004,0.063013)$ & $0.060274(-0.064493,0.185040)$ & $0.000000(0.000000,0.000000)$ \\
\hline & 2013 & $0.013863(-0.005643,0.033369)$ & $0.021661(-0.022527,0.065849)$ & $0.000000(0.000000,0.000000)$ \\
\hline & 2014 & $0.000000(0.000000,0.000000)$ & $0.000000(0.000000,0.000000)$ & $0.000000(0.000000,0.000000)$ \\
\hline & 2015 & $0.008774(-0.003471,0.021019)$ & $0.024321(-0.010106,0.058748)$ & $0.000000(0.000000,0.000000)$ \\
\hline \multirow{10}{*}{$\begin{array}{l}\text { Proportion non-ze- } \\
\text { ro }(95 \% \mathrm{Cl})\end{array}$} & 2006 & $0.032258(0.005717,0.161941)$ & $0.000000(0.000000,0.193608)$ & $0.000000(0.000000,0.489891)$ \\
\hline & 2007 & $0.000000(0.000000,0.107179)$ & $0.000000(0.000000,0.657620)$ & $0.000000(0.000000,0.299145)$ \\
\hline & 2008 & $0.000000(0.000000,0.077074)$ & $0.000000(0.000000,0.299145)$ & $0.000000(0.000000,0.434482)$ \\
\hline & 2009 & $0.015625(0.002764,0.083341)$ & $0.052632(0.009352,0.246387)$ & $0.000000(0.000000,0.215311)$ \\
\hline & 2010 & $0.035714(0.009849,0.121188)$ & $0.045455(0.008069,0.217980)$ & $0.000000(0.000000,0.354330)$ \\
\hline & 2011 & $0.015625(0.002764,0.083341)$ & $0.043478(0.007717,0.209912)$ & $0.000000(0.000000,0.324408)$ \\
\hline & 2012 & $0.015152(0.002680,0.080959)$ & $0.043478(0.007717,0.209912)$ & $0.000000(0.000000,0.242494)$ \\
\hline & 2013 & $0.020000(0.005502,0.070012)$ & $0.031250(0.005538,0.157443)$ & $0.000000(0.000000,0.193608)$ \\
\hline & 2014 & $0.000000(0.000000,0.034347)$ & $0.000000(0.000000,0.098901)$ & $0.000000(0.000000,0.161125)$ \\
\hline & 2015 & $0.012658(0.003478,0.044973)$ & $0.035088(0.009676,0.119208)$ & $0.000000(0.000000,0.124555)$ \\
\hline \multirow{10}{*}{$\begin{array}{l}\text { MNLCS - mean } \\
(95 \% \mathrm{CI}) \text { of world } \\
\text { normalized log } \\
\text { (1_unique URLs) }\end{array}$} & 2006 & $1.000000(\mathrm{NaN}, \mathrm{NaN})$ & $0.000000(\mathrm{NaN}, \mathrm{NaN})$ & $0.000000(\mathrm{NaN}, \mathrm{NaN})$ \\
\hline & 2007 & $\mathrm{NaN}(\mathrm{NaN}, \mathrm{NaN})$ & $\mathrm{NaN}(\mathrm{NaN}, \mathrm{NaN})$ & $\mathrm{NaN}(\mathrm{NaN}, \mathrm{NaN})$ \\
\hline & 2008 & $\mathrm{NaN}(\mathrm{NaN}, \mathrm{NaN})$ & $\mathrm{NaN}(\mathrm{NaN}, \mathrm{NaN})$ & $\mathrm{NaN}(\mathrm{NaN}, \mathrm{NaN})$ \\
\hline & 2009 & $1.000000(\mathrm{NaN}, \mathrm{NaN})$ & $3.368421(\mathrm{NaN}, \mathrm{NaN})$ & $0.000000(\mathrm{NaN}, \mathrm{NaN})$ \\
\hline & 2010 & $1.000000(\mathrm{NaN}, \mathrm{NaN})$ & $1.272727(\mathrm{NaN}, \mathrm{NaN})$ & $0.000000(\mathrm{NaN}, \mathrm{NaN})$ \\
\hline & 2011 & $1.000000(\mathrm{NaN}, \mathrm{NaN})$ & $2.782609(\mathrm{NaN}, \mathrm{NaN})$ & $0.000000(\mathrm{NaN}, \mathrm{NaN})$ \\
\hline & 2012 & $1.000000(\mathrm{NaN}, \mathrm{NaN})$ & $2.869565(\mathrm{NaN}, \mathrm{NaN})$ & $0.000000(\mathrm{NaN}, \mathrm{NaN})$ \\
\hline & 2013 & $1.000000(\mathrm{NaN}, \mathrm{NaN})$ & $1.562500(\mathrm{NaN}, \mathrm{NaN})$ & $0.000000(\mathrm{NaN}, \mathrm{NaN})$ \\
\hline & 2014 & $\mathrm{NaN}(\mathrm{NaN}, \mathrm{NaN})$ & $\mathrm{NaN}(\mathrm{NaN}, \mathrm{NaN})$ & $\mathrm{NaN}(\mathrm{NaN}, \mathrm{NaN})$ \\
\hline & 2015 & $1.000000(\mathrm{NaN}, \mathrm{NaN})$ & $2.771930(\mathrm{NaN}, \mathrm{NaN})$ & $0.000000(\mathrm{NaN}, \mathrm{NaN})$ \\
\hline \multirow{10}{*}{$\begin{array}{l}\text { EMNPC - world nor- } \\
\text { malized proportion } \\
\text { non-zero }(95 \% \mathrm{CI}) \\
\text { [ie risk ratio] }\end{array}$} & 2006 & $1.000000(0.109949,9.095124)$ & $0.000000(0.000000,0.124555)$ & $0.000000(0.000000,0.124555)$ \\
\hline & 2007 & $0.000000(\mathrm{NaN}, \mathrm{NaN})$ & $0.000000(\mathrm{NaN}, \mathrm{NaN})$ & $0.000000(\mathrm{NaN}, \mathrm{NaN})$ \\
\hline & 2008 & $0.000000(\mathrm{NaN}, \mathrm{NaN})$ & $0.000000(\mathrm{NaN}, \mathrm{NaN})$ & $0.000000(\mathrm{NaN}, \mathrm{NaN})$ \\
\hline & 2009 & $1.000000(0.106833,9.360444)$ & $3.368421(0.371563,30.536600)$ & $0.000000(0.000000,0.000000)$ \\
\hline & 2010 & $1.000000(0.180240,5.548168)$ & $1.272727(0.178693,9.064912)$ & $0.000000(0.000000,0.000000)$ \\
\hline & 2011 & $1.000000(0.106833,9.360444)$ & $2.782609(0.304509,25.427506)$ & $0.000000(0.000000,0.000000)$ \\
\hline & 2012 & $1.000000(0.106746,9.368058)$ & $2.869565(0.313896,26.232896)$ & $0.000000(0.000000,0.000000)$ \\
\hline & 2013 & $1.000000(0.177108,5.646260)$ & $1.562500(0.214718,11.370277)$ & $0.000000(0.000000,0.000000)$ \\
\hline & 2014 & $0.000000(\mathrm{NaN}, \mathrm{NaN})$ & $0.000000(\mathrm{NaN}, \mathrm{NaN})$ & $0.000000(\mathrm{NaN}, \mathrm{NaN})$ \\
\hline & 2015 & $1.000000(0.175675,5.692336)$ & $2.771930(0.493049,15.583837)$ & $0.000000(0.000000,0.000000)$ \\
\hline
\end{tabular}


Table 10. Industrial and commercial impact of AM technologies for biomedical engineering applications

Industrial and commercial impact

\begin{tabular}{|c|c|c|c|c|}
\hline \multicolumn{5}{|c|}{ - Google Patents citation counts - } \\
\hline Indicators & Year & World & USA & China \\
\hline \multirow{10}{*}{$\begin{array}{l}\text { Arithmetic mean } \\
\text { (unique domains) }\end{array}$} & 2006 & 0.580645 & 0.687500 & 1.000000 \\
\hline & 2007 & 0.500000 & 0.666667 & 0.500000 \\
\hline & 2008 & 0.304348 & 0.444444 & 0.400000 \\
\hline & 2009 & 0.468750 & 0.578947 & 0.571429 \\
\hline & 2010 & 0.428571 & 0.409091 & 0.714286 \\
\hline & 2011 & 0.375000 & 0.391304 & 0.625000 \\
\hline & 2012 & 0.257576 & 0.260870 & 0.500000 \\
\hline & 2013 & 0.240000 & 0.406250 & 0.125000 \\
\hline & 2014 & 0.259259 & 0.342857 & 0.250000 \\
\hline & 2015 & 0.170886 & 0.228070 & 0.259259 \\
\hline \multirow{10}{*}{$\begin{array}{l}\text { Geometric mean } \\
(95 \% \mathrm{Cl}) \text { of unique } \\
\text { domains }\end{array}$} & 2006 & $0.495518(0.316637,0.698702)$ & $0.610490(0.349650,0.921742)$ & $1.000000(1.000000,1.000000)$ \\
\hline & 2007 & $0.414214(0.245567,0.605694)$ & $0.587401(0.215598,1.072923)$ & $0.414214(-0.982723,114.760560)$ \\
\hline & 2008 & $0.234860(0.121781,0.359338)$ & $0.360790(0.027130,0.802838)$ & $0.319508(-0.176956,1.115441)$ \\
\hline & 2009 & $0.383910(0.268399,0.509941)$ & $0.493759(0.260997,0.769486)$ & $0.485994(0.209963,0.824997)$ \\
\hline & 2010 & $0.345900(0.225848,0.477710)$ & $0.327849(0.137548,0.549986)$ & $0.640671(0.19950,1.244095)$ \\
\hline & 2011 & $0.296840(0.191693,0.411264)$ & $0.311579(0.129684,0.522761)$ & $0.542211(0.141819,1.083004)$ \\
\hline & 2012 & $0.195468(0.108874,0.288825)$ & $0.198201(0.047594,0.370459)$ & $0.414214(0.123763,0.779735)$ \\
\hline & 2013 & $0.180993(0.112768,0.253400)$ & $0.325237(0.169832,0.501285)$ & $0.090508(-0.038661,0.237032)$ \\
\hline & 2014 & $0.196864(0.128596,0.269262)$ & $0.268266(0.130368,0.422986)$ & $0.189207(0.029811,0.373275)$ \\
\hline & 2015 & $0.125750(0.080280,0.173133)$ & $0.171267(0.082832,0.266925)$ & $0.196864(0.058642,0.353132)$ \\
\hline \multirow{10}{*}{$\begin{array}{l}\text { Mean }(95 \% \mathrm{CI}) \\
\text { of log(1+unique } \\
\text { domains) }\end{array}$} & 2006 & $0.402473(0.275081,0.529864)$ & $0.476539(0.299845,0.653232)$ & $0.693147(0.693147,0.693147)$ \\
\hline & 2007 & $0.346574(0.219591,0.473556)$ & $0.462098(0.195236,0.728960)$ & $0.346574(-4.058377,4.751524)$ \\
\hline & 2008 & $0.210958(0.114918,0.306998)$ & $0.308065(0.026769,0.589362)$ & $0.277259(-0.194745,0.749263)$ \\
\hline & 2009 & $0.324913(0.237755,0.412070)$ & $0.401296(0.231902,0.570689)$ & $0.396084(0.190590,0.601579)$ \\
\hline & 2010 & $0.297063(0.203633,0.390493)$ & $0.283560(0.128875,0.438246)$ & $0.495105(0.181908,0.808302)$ \\
\hline & 2011 & $0.259930(0.175375,0.344485)$ & $0.271232(0.121938,0.420525)$ & $0.433217(0.132623,0.733811)$ \\
\hline & 2012 & $0.178538(0.103345,0.253731)$ & $0.180821(0.046496,0.315146)$ & $0.346574(0.116683,0.576465)$ \\
\hline & 2013 & $0.166355(0.106851,0.225860)$ & $0.281591(0.156860,0.406322)$ & $0.086643(-0.039429,0.212715)$ \\
\hline & 2014 & $0.179705(0.120974,0.238435)$ & $0.237650(0.122543,0.352758)$ & $0.173287(0.029375,0.317198)$ \\
\hline & 2015 & $0.118449(0.077220,0.159678)$ & $0.158086(0.079580,0.236593)$ & $0.179705(0.056987,0.302422)$ \\
\hline \multirow{10}{*}{$\begin{array}{l}\text { Proportion } \\
\text { non-zero }(95 \% \mathrm{Cl})\end{array}$} & 2006 & $0.580645(0.407663,0.735845)$ & $0.687500(0.444044,0.858354)$ & $1.000000(0.510109,1.000000)$ \\
\hline & 2007 & $0.500000(0.336309,0.663691)$ & $0.666667(0.354202,0.879416)$ & $0.500000(0.094531,0.905469)$ \\
\hline & 2008 & $0.304348(0.190798,0.448056)$ & $0.444444(0.188779,0.733349)$ & $0.400000(0.117621,0.769276)$ \\
\hline & 2009 & $0.468750(0.351760,0.589279)$ & $0.578947(0.362759,0.768581)$ & $0.571429(0.325906,0.786192)$ \\
\hline & 2010 & $0.428571(0.307690,0.558624)$ & $0.409091(0.232558,0.612652)$ & $0.714286(0.358934,0.917781)$ \\
\hline & 2011 & $0.375000(0.266660,0.497496)$ & $0.391304(0.221576,0.592145)$ & $0.625000(0.305742,0.863156)$ \\
\hline & 2012 & $0.257576(0.167488,0.374331)$ & $0.260870(0.125486,0.464700)$ & $0.500000(0.253782,0.746218)$ \\
\hline & 2013 & $0.240000(0.166913,0.332323)$ & $0.406250(0.255196,0.577400)$ & $0.125000(0.034977,0.360228)$ \\
\hline & 2014 & $0.259259(0.185891,0.349165)$ & $0.342857(0.208317,0.508481)$ & $0.250000(0.111862,0.468701)$ \\
\hline & 2015 & $0.170886(0.120183,0.237213)$ & $0.228070(0.138419,0.352060)$ & $0.259259(0.131704,0.446786)$ \\
\hline \multirow{10}{*}{$\begin{array}{l}\text { MNLCS - mean } \\
(95 \% \mathrm{Cl}) \text { of world } \\
\text { normalized log } \\
\text { (1_unique do- } \\
\text { mains) }\end{array}$} & 2006 & $1.000000(0.632776,1.580339)$ & $1.184028(0.711693,1.914321)$ & $1.722222(1.308160,2.519795)$ \\
\hline & 2007 & $1.000000(0.584017,1.712279)$ & $1.333333(0.616767,2.463397)$ & $1.000000(-1.077876,3.387999)$ \\
\hline & 2008 & $1.000000(0.496709,2.013251)$ & $1.460317(0.286993,3.397228)$ & $1.314286(-0.317905,3.633703)$ \\
\hline & 2009 & $1.000000(0.679000,1.472754)$ & $1.235088(0.703875,1.957830)$ & $1.219048(0.610937,2.016201)$ \\
\hline & 2010 & $1.000000(0.631677,1.583088)$ & $0.954545(0.435792,1.678302)$ & $1.666667(0.772978,2.918297)$ \\
\hline & 2011 & $1.000000(0.620921,1.610510)$ & $1.043478(0.468033,1.865901)$ & $1.666667(0.666941,3.060869)$ \\
\hline & 2012 & $1.000000(0.528419,1.892436)$ & $1.012788(0.276594,2.185739)$ & $1.941176(0.730814,3.988658)$ \\
\hline & 2013 & $1.000000(0.589018,1.697742)$ & $1.692708(0.898465,2.972352)$ & $0.520833(-0.194141,1.388639)$ \\
\hline & 2014 & $1.000000(0.619412,1.614436)$ & $1.322449(0.664615,2.289534)$ & $0.964286(0.202781 ., 1.951286)$ \\
\hline & 2015 & $1.000000(0.594978,1.680734)$ & $1.334633(0.647040,2.390200)$ & $1.517147(0.505898,2.946691)$ \\
\hline \multirow{10}{*}{$\begin{array}{l}\text { EMNPC - world } \\
\text { normalized pro- } \\
\text { portion non-zero } \\
(95 \% \text { Cl) [i.e. risk } \\
\text { ratio] }\end{array}$} & 2006 & $1.000000(0.664172,1.505635)$ & $1.184028(0.776782,1.804782)$ & $1.722222(\mathrm{NaN}, \mathrm{NaN})$ \\
\hline & 2007 & $1.000000(0.621941,1.607871)$ & $1.333333(0.787758,2.256756)$ & $1.000000(0.419890,2.381578)$ \\
\hline & 2008 & $1.000000(0.547518,1.826422)$ & $1.460317(0.669484,3.185330)$ & $1.314286(0.495971,3.482756)$ \\
\hline & 2009 & $1.000000(0.695506,1.437803)$ & $1.235088(0.791688,1.926821)$ & $1.219048(0.744264,1.996708)$ \\
\hline & 2010 & $1.000000(0.657052,1.521950)$ & $0.954545(0.543139,1.677576)$ & $1.666667(1.023382,2.714312)$ \\
\hline & 2011 & $1.000000(0.644078,1.552606)$ & $1.043478(0.585395,1.860019)$ & $1.666667(0.950797,2.921527)$ \\
\hline & 2012 & $1.000000(0.56666,1.764722)$ & $1.012788(0.471267,2.176556)$ & $1.941176(1.005908,3.746036)$ \\
\hline & 2013 & $1.000000(0.614726,1.626742)$ & $1.692708(0.994474,2.881182)$ & $0.520833(0.158530,1.711138)$ \\
\hline & 2014 & $1.000000(0.640527,1.561214)$ & $1.322449(0.766984,2.280193)$ & $0.964286(0.442831,2.099777)$ \\
\hline & 2015 & $1.000000(0.618556,1.616668)$ & $1.334633(0.749760,2.375753)$ & $1.517147(0.755935,3.044883)$ \\
\hline
\end{tabular}




\section{Discussion}

The findings from this work suggest that AM technologies for biomedical engineering applications are emerging technologies, i.e. they are at an early stage of development, which agrees with the results obtained by other studies for additive manufacturing technologies (Rodríguez-Salvador; Río-Belver; Garechana-Anacabe, 2017; Zarrabeitia-Bilbao et al., 2019).

Within this scenario, the USA and China are undoubtedly the central characters in scientific production in this field. In this case, the USA shows the supremacy also demonstrated in other studies related to both research areas, additive manufacturing, and medicine; however, in the case of China it seems that this position is due to the area of the technology and not to the medicine. While in other studies related to the technology, both countries are among the first positions, in the case of China, in other studies related to medicine it does not appear in the first positions of the countries with more publications (López-Muñoz et al., 2003; López-Illescas; De-Moya-Anegón; Moed, 2009; Filser; Da-Silva; De-Oliveira, 2017; Rodríguez-Salvador; Río-Belver; Garechana-Anacabe, 2017; Caviggioli; Ughetto, 2019; Muhuri; Shukla; Abraham, 2019).

The top publishing and cited institutions, as expected, are universities. However, the presence of certain laboratories or medical centers is omitted. Due to this, it would be interesting, for future works, to include an analysis of the departments (Filser; Da-Silva; De-Oliveira, 2017) which were involved in the published articles and analyze if there are more medical or more technical departments.

The findings from academic impact and industrial and commercial impact indicators suggest that AM technologies for biomedical engineering application research, in general, produces good results, and, consequently, fine quality research is performed.

In the case of citation counts for individual sets of articles, this emphasizes that the proportion of articles with at least 1 citation practically $100 \%$ (98.7\%).

For Mendeley readers count it is observed that the proportion of articles with at least 1 Mendeley reader is $97.5 \%$, while the proportion with at least one Mendeley reader varied from $40.7 \%$ in humanities to $81 \%$ in psychology $(72.4 \%$ for biomedical research and $71.6 \%$ for engineering and technology) for articles from 2010 to 2012 in PubMed and Web of Science (Haustein et al., 2014). There is a high level of interest among researchers in biomedical engineering applications.

In the case of Google Patents citation counts, the proportion of articles with at least 1 Google Patents citation is 35.9\%, while the coverage in applied science and engineering varies for $1.9 \%$ in mechanical engineering to $10.1 \%$ in biomedical engineering for articles from 1996 to 2012 in Scopus (Kousha; Thelwall, 2017b). Therefore, we can say that a high rate of transfer between science and technology is taking place.

As for Wikipedia citation counts, the proportion of articles with at least 1 Wikipedia citation is only $1.5 \%$, whereas the proportion with at least one Wikipedia citation varied from $1.4 \%$ in Computer Science to $10.7 \%$ in History for articles from 2005 to 2012 in Scopus (Kousha; Thelwall, 2017a). More time is required for new research and its applications to be broadly transferred to the academic field.

\subsection{Limitations and other considerations}

Finally, the present study, like all bibliometric/webometric analyses, has its inherent methodological limitations. Reliability of bibliometric data can be affected by the bibliometric database coverage (Web of Science). The impact indicators used show academic, and industrial and commercial impact, and have been used as a proxy for quality. However, estimates of quality based on these variables can be misleading because work may be cited for a variety of reasons, not all of which may reflect quality (Gunashekar et al., 2015).
The USA shows the supremacy also demonstrated in other studies related to both research areas, additive manufacturing, and medicine; however, in the case of China it seems that this position is due to the area of the technology and not to the medicine

Hence, despite the fact that bibliometric/webometric analysis has been used increasingly as a tool within the scientific community (Ellegaard, 2018) and bibliometric/webometric methods offer a practical and impartial way to estimate publication profiles of scientific researchers, it would also be interesting to complete the results obtained with other methods, such as expert opinions and panels (Koskinen et al., 2008). 


\section{Conclusions and future lines of research}

This research contributes to the diffusion of technologies to society, providing key elements to scientific and technological policy makers. Usually main productivity impact studies come from firms and follow a variety of methodological approaches. This paper addressing trends and the scientific impact of additive manufacturing technologies for biomedical engineering applications provides evidence on the generation and impact of scientific production from bibliometric data and suggests only one methodological approach for every study, which may be extended to other fields.

Additive manufacturing technologies have been identified as revolutionary because of their power to change, among other things, productive systems, skills and weIl-being; and they will have major implications for society, in general; and for policy makers, in particular.

In general, in AM technologies for BE applications is worth noting the clear agreement between where knowledge comes from and who is researching it (countries and institutions), except for the case of China, who, despite extensive research activity, would appear to have contributed relatively little to that field to date.

The greatest research areas from where the knowledge comes and research areas developed, are in both cases "Engineering, Biomedical" and "Materials Science, Biomaterials". It can also be deduced that the different areas of knowledge are following the same paths, for both where the knowledge comes from and where it goes. In addition, the fields of research have evolved very little, in general, inferring that they cover the same topics.

With respect to scientific journals, the most prolific journals and the most cited journals are in upper quartile rankings, which demonstrates the quality of the articles being published in the area.

Another important point to highlight is that the USA, apart from being the central character in scientific production, produces scientific studies into AM technologies for biomedical engineering applications that have higher academic, industrial, and commercial impact than the world average. This is not the case for China, the second most productive country in the area for academic impact but with merely good results in terms of industrial and commercial impact.

Finally, future work related with this study could take many forms, given the diversity of the current situation for additive manufacturing and informetrics. It would be interesting to analyze specific AM technologies and their behavior in different biomedical engineering applications. Further research should also use other primary search engines (like Scopus) and other scientific impact indicators. New scientific impact indicators could be Google Books citations and citations from the Grey Literature (academic impact); Syllabus mentions (educational impact); Clinical Trials or Guidelines (medical impact); and Blog citations (public engagement impact). Finally, it would also be interesting to expand this study to include other processes and technologies.

\section{Notes}

1. A top technician was identified through Addimat (the Spanish Association of Additive Manufacturing Technologies and $3 D, h t t p: / / w w w . a d d i m a t . e s)$. At the time of furnishing assistance, the expert selected was a qualified engineer from $O p$ timus3D (http://optimus3d.es), a company that provides comprehensive engineering and part manufacturing solutions, using different additive manufacturing technologies, both in plastic materials or resins, as well as metal.

2. MNLCS is the average number of log-transformed citations for the group, divided by the average number of log-transformed citations for the corresponding world set (Thelwall, 2016).

3. EMNPC is the proportion of articles cited for the group, divided by the corresponding world proportion of cited articles for the same field and year (Thelwall, 2016).

4. NaN (Not a Number) in the sample confidence limits mean that these are impossible to calculate and are effectively infinite.

5. Even though normally unique domains value is best information value (to avoid counting multiple similar pages in a single website), in the case of Wikipedia URLs value is better (Kousha; Thelwall, 2017a). 


\section{Appendix}

Search query for Additive Manufacturing for Biomedical Engineering Applications adapted to the Web of Science Core Collection database

\begin{tabular}{|c|c|}
\hline Equation (1) [World] & 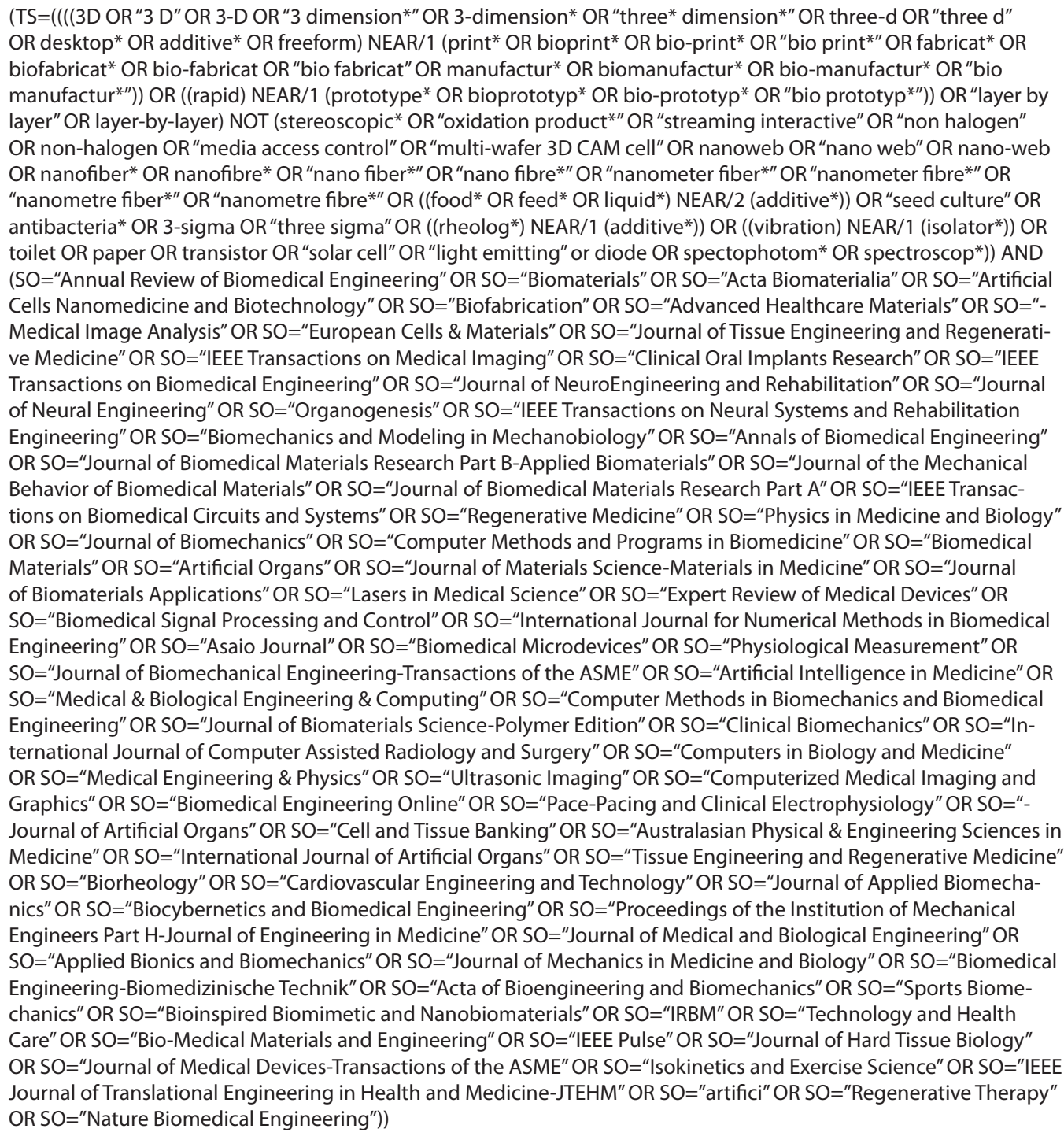 \\
\hline Equation (2) [USA] & Equation (1) AND (AD=USA) \\
\hline Equation (3) [China] & Equation (1) AND (AD=China) \\
\hline Source & Web of Science \\
\hline Databases & Core Collection \\
\hline Timespan (1) & From 2000 to 2017 \\
\hline Timespan (2) & From 2006 to 2015 \\
\hline Document type & Articles \\
\hline Date of the search & October 01, 2018 \\
\hline $\begin{array}{l}\text { Results [equation (1) + } \\
\text { timespan (1)] }\end{array}$ & 1223 articles \\
\hline $\begin{array}{l}\text { Results [equation (1)+ } \\
\text { timespan (2)] }\end{array}$ & $\begin{array}{l}31 \text { articles (in 2006), } 32 \text { articles (in 2007), } 46 \text { articles (in 2008), } 64 \text { articles (in 2009), } 56 \text { articles (in 2010), } 64 \text { articles (in } \\
2011 \text { ), } 66 \text { articles (in 2012), } 100 \text { articles (in 2013), } 108 \text { articles (in 2014), } 158 \text { articles (in 2015) }\end{array}$ \\
\hline $\begin{array}{l}\text { Results [equation (2) + } \\
\text { timespan (2)] }\end{array}$ & $\begin{array}{l}16 \text { articles (in 2006), } 9 \text { articles (in 2007), } 9 \text { articles (in 2008), } 19 \text { articles (in 2009), } 22 \text { articles (in 2010), } 23 \text { articles (in } \\
2011 \text { ), } 23 \text { articles (in 2012), } 32 \text { articles (in 2013), } 35 \text { articles (in 2014), } 57 \text { articles (in 2015) }\end{array}$ \\
\hline $\begin{array}{l}\text { Results [equation (3) + } \\
\text { timespan (2)] }\end{array}$ & $\begin{array}{l}4 \text { articles (in 2006), } 2 \text { articles (in 2007), } 5 \text { articles (in 2008), } 14 \text { articles (in 2009), } 7 \text { articles (in 2010), } 8 \text { articles (in 2011), } \\
12 \text { articles (in 2012), } 16 \text { articles (in 2013), } 20 \text { articles (in 2014), } 27 \text { articles (in 2015) }\end{array}$ \\
\hline
\end{tabular}




\section{References}

Aduku, Kuku-Joseph; Thelwall, Mike; Kousha, Kayvan (2017). “Do Mendeley reader counts reflect the scholarly impact of conference papers? An investigation of computer science and engineering". Scientometrics, v. 112, n. 1, pp. 573-581. https://doi.org/10.1007/s11192-017-2367-1

AM Platform (2014). Additive manufacturing: Strategic research agenda. http://www.rm-platform.com/linkdoc/AM SRA - February 2014.pdf

Ardanuy, Jordi (2012). Breve introducción a la bibliometría. Universitat de Barcelona. http://diposit.ub.edu/dspace/bitstream/2445/30962/1/breve\%20introduccion\%20bibliometria.pdf

Bourell, David L.; Leu, Ming C.; Rosen, David W. (2009). Roadmap for additive manufacturing. Identifying the future of freeform processing. The University of Texas at Austin.

https://wohlersassociates.com/roadmap2009A.pdf

Campbell, Thomas; Williams, Christopher; Ivanova, Olga; Garrett, Banning (2011). Could 3D printing change the World? Technologies, potential, and implications of additive manufacturing". Atlantic Council. Strategic Foresight Report. http://globaltrends.thedialogue.org/wp-content/uploads/2014/11/Could-3D-Printing-Change-the-World-TechnologiesPotential-and-Implications-of-Additive-Manufacturing.pdf

Caviggioli, Federico; Ughetto, Elisa (2019). "A bibliometric analysis of the research dealing with the impact of additive manufacturing on industry, business and society". International journal of production economics, v. 208, pp. 254-268. https://doi.org/10.1016/j.ijpe.2018.11.022

Clarivate (2018). Web of Science. Clarivate. https://clarivate.com/products/web-of-science

Cruickshank, Michael (2017). "Additive manufacturing: Another layer to industry 4.0". The manufacturer, 16 November. https://www.themanufacturer.com/articles/additive-manufacturing-another-layer-to-industry-4-0

Diem, Andrea; Wolter, Stefan C. (2013). "The use of bibliometrics to measure research performance in education sciences". Research in higher education, v. 54, n. 1, pp. 86-114.

https://doi.org/10.1007/s11162-012-9264-5

Ellegaard, Ole (2018). "The application of bibliometric analysis: Disciplinary and user aspects". Scientometrics, v. 116, n. 1, pp. 181-202.

https://doi.org/10.1007/s11192-018-2765-z

Filser, Lukas-Daniel; Da-Silva, Fábio-Francisco; De-Oliveira, Otávio-José (2017). "State of research and future research tendencies in lean healthcare: A bibliometric analysis". Scientometrics, v. 112, n. 2, pp. 799-816.

https://doi.org/10.1007/s11192-017-2409-8

Gridlogics Technologies Pvt Ltd (2014). 3-D printing: Technology insight report. An analysis of patenting activity around 3D-Printing from 1990-Current. Patent Insight Pro.

https://www.patentinsightpro.com/techreports/0214/Tech\%20Insight\%20Report\%20-\%203D\%20Printing.pdf

Gunashekar, Salil; Lavoie, Rémi; Roberge, Guillaume; Rashid, Mohammed; Marjanovic, Sonja (2015). A bibliometric analysis of research by the Cambridge Neuroscience Strategic Research Initiative: Extended summary. Rand Europe; Science-Metrix.

https://www.rand.org/content/dam/rand/pubs/research_reports/RR1100/RR1189/RAND_RR1189.pdf

Haustein, Stefanie; Larivière, Vincent; Thelwall, Mike; Amyot, Didier; Peters, Isabella (2014). "Tweets vs. Mendeley readers: How do these two social media metrics differ?”. Information technology, v. 56, n. 5, pp 207-215.

https://arxiv.org/pdf/1410.0569.pdf

https://doi.org/10.1515/itit-2014-1048

Holmberg, Kim (2015). Altmetrics for information professionals: Past, present and future. ISBN: 9780081002773

Jing, Su; Qinghua, Zhai; Landström, Hans (2017). “Entrepreneurship across regions: Internationalization and/or contextualization?”. In: Carmo-Farinha, Luis M.; Ferreira, João J. M.; Lawton, Helen; Bagchi-Sen, Sharmistha. Handbook of research on global competitive advantage through innovation and entrepreneurship, pp. 731-752. ISBN: 9781466683488 https://doi.org/10.4018/978-1-4666-8348-8.ch022

Koskinen, Johanna; Isohanni, Matti; Paajala, Henna; Jääskeläinen, Erika; Nieminen, Pentti; Koponen, Hannu; Tienari, Pekka; Miettunen, Jouko (2008). "How to use bibliometric methods in evaluation of scientific research? An example from Finnish schizophrenia research". Nordic journal of psychiatry, v. 62, n. 2, pp. 136-143.

https://doi.org/10.1080/08039480801961667 
Kousha, Kayvan; Thelwall, Mike (2017a). "Are Wikipedia citations important evidence of the impact of scholarly articles and books?" Journal of the Association for Information Science and Technology, v. 68, n. 3, pp. 762-779.

https://doi.org/10.1002/asi.23694

Kousha, Kayvan; Thelwall, Mike (2017b). "Patent citation analysis with Google". Journal of the Association for Information Science and Technology, v. 68, n. 1, pp. 48-61.

https://doi.org/10.1002/asi.23608

López-Illescas, Carmen; De-Moya-Anegón, Félix; Moed, Henk F. (2009). “Comparing bibliometric country-by-country rankings derived from the Web of Science and Scopus: The effect of poorly cited journals in oncology". Journal of information science, v. 35, n. 2, pp. 244-256.

https://doi.org/10.1177/0165551508098603

López-Muñoz, Francisco; Alamo, Cecilio; Rubio, Gabriel; García-García, Pilar; Martín-Agueda, Belén; Cuenca, Eduardo (2003). "Bibliometric analysis of biomedical publications on SSRI during 1980-2000". Depression and anxiety, v. 18, n. 2 , pp. 95-103.

https://doi.org/10.1002/da.10121

Marx, Werner; Bornmann, Lutz (2016). "Change of perspective: bibliometrics from the point of view of cited references - A literature overview on approaches to the evaluation of cited references in bibliometrics". Scientometrics, v. 109, n. 2, pp. 1397-1415.

https://doi.org/10.1007/s11192-016-2111-2

Muhuri, Pranab K.; Shukla, Amit K.; Abraham, Ajith (2019). "Industry 4.0: A bibliometric analysis and detailed overview". Engineering applications of artificial intelligence, v. 78, pp. 218-235.

https://doi.org/10.1016/j.engappai.2018.11.007

OECD (2016). Enabling the next production revolution: the future of manufacturing and services. Interim report. Meeting of the OECD Council at Ministerial Level.

https://www.oecd.org/mcm/documents/Enabling-the-next-production-revolution-the-future-of-manufacturing-andservices-interim-report.pdf

Quarshie, Robert; MacLachlan, Stuart; Reeves, Phil; Whittaker, David; Blake, Robert (2012). Shaping our national competency in additive manufacturing. Additive Manufacturing. Special Interest Group.

https://docplayer.net/7645943-Shaping-our-national-competency-in-additive-manufacturing.html

Rodríguez-Salvador, Marisela; Río-Belver, Rosa-María; Garechana-Anacabe, Gaizka (2017). "Scientometric and patentometric analyses to determine the knowledge landscape in innovative technologies: The case of 3D bioprinting". PLoS one, v. 12, n. 6, e0180375.

https://doi.org/10.1371/journal.pone.0180375

Singh, Sunpreet; Ramakrishna, Seeram (2017). "Biomedical applications of additive manufacturing: Present and future". Current opinion in biomedical engineering, v. 2, pp. 105-115.

https://doi.org/10.1016/j.cobme.2017.05.006

Thelwall, Mike (2009a). Introduction to Webometric analyst 2.0: A research tool for social scientists. http://lexiurl.w/v.ac.uk/searcher/IntroductionToWebometricAnalyst2.doc

Thelwall, Mike (2009b). "Introduction to Webometrics: Quantitative web research for the social sciences". Information concepts, retrieval, and services, v. 1, n. 1.

https://doi.org/10.2200/S00176ED1V01Y200903ICR004

Thelwall, Mike (2016). "Web indicators for research evaluation: A practical guide". Information concepts, retrieval, and services, v. 8, n. 4.

https://doi.org/10.2200/S00733ED1V01Y201609ICR052

Thelwall, Mike (2018). Statistical cybermetrics. Research Group.

http://cybermetrics.wlv.ac.uk

Thelwall, Mike; Kousha, Kayvan (2015a). "Web indicators for research evaluation. Part 1: Citations and links to academic articles from the Web". El profesional de la información, v. 24, n. 5, p. 587.

https://doi.org/10.3145/epi.2015.sep.08

Thelwall, Mike; Kousha, Kayvan (2015b). "Web indicators for research evaluation. Part 2: Social media metrics". El profesional de la información, v. 24, n. 5, pp. 607-620.

https://doi.org/10.3145/epi.2015.sep.09 
Thelwall, Mike; Sud, Pardeep (2018). "A comparison of title words for journals articles and Wikipedia pages: Coverage and stylistic differences?". El profesional de la información, v. 27, n. 1, pp. 49-64.

https://doi.org/10.3145/epi.2018.ene.05

Tjahjono, Benny; Esplugues, C.; Ares, Enrique; Peláez, Gerardo C. (2017). "What does industry 4.0 mean to supply chain?". Procedia manufacturing, v. 13, pp. 1175-1182.

https://doi.org/10.1016/j.promfg.2017.09.191

Van-Eck, Nees-Jan; Waltman, Ludo (2007). "VOS: A new method for visualizing similarities between objects". In: Decker, Reinhold; Lenz, Hans-Joachim (eds.). Advances in data analysis. Studies in classification, data analysis, and knowledge organization. Berlin, Heidelberg: Springer, pp. 299-306. ISBN: 9783540709800

https://doi.org/10.1007/978-3-540-70981-7_34

Van-Eck, Nees-Jan; Waltman, Ludo (2009). "How to normalize cooccurrence data? An analysis of some well-known similarity measures". Journal of the American Society for Information Science and Technology, v. 60, n. 8, pp. 1635-1651. https://doi.org/10.1002/asi.21075

Van-Eck, Nees-Jan; Waltman, Ludo (2010). "Software survey: VOSviewer, a computer program for bibliometric mapping." Scientometrics, v. 84, n. 2, pp. 523-538.

https://doi.org/10.1007/s11192-009-0146-3

Van-Eck, Nees-Jan; Waltman, Ludo (2011). "Text mining and visualization using VOSviewer". ISSI newsletter, v. 7, n. 3, pp. 50-54.

http://arxiv.org/abs/1109.2058

VantagePoint (2018). The VantagePoint.

https://www.thevantagepoint.com

VOSviewer (2018). "VOSviewer. Visualizing scientific landscapes.

http://www.vosviewer.com

Waltman, Ludo; Van-Eck, Nees-Jan; Noyons, Ed C. M. (2010). "A unified approach to mapping and clustering of bibliometric networks". Journal of informetrics, v. 4, n. 4, pp. 629-635.

http://arxiv.org/abs/1006.1032

Zarrabeitia-Bilbao, Enara; Bildosola, Iñaki; Río-Belver, Rosa-María; Álvarez-Meaza, Izaskun; Cilleruelo-Carrasco, Ernesto (2019). "Laser additive manufacturing: A patent overview". Engineering digital transformation, pp. 183-191.

https://doi.org/10.1007/978-3-319-96005-0_23

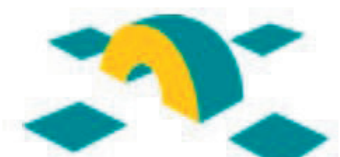

https://www.rediris.es/list/info/iwetel.htm

\section{¿्याRIS IWETEL}

Foro para profesionales de

Con unos 6.000 miembros, IweTel es la mayor lista de distribución en castellano para debatir y estar al día sobre temas de biblioteconomía y documentación.

Fue creada en 1993 por Tomàs Baiget, como complemento de Information World en Español (IWE), revista que en 1999 pasó a denominarse El profesional de la información (EP/).

Desde 1998 IweTel está alojada en el servicio de listas de RedIRIS, siendo posible consultar en sus archivos estos 18 años de la historia de la documentación en España:

https://listserv.rediris.es/cgi-bin/wa?A0=IWETEL

La lista cuenta con 4 moderadores que permanentemente filtran los mensajes para evitar spam, men-

sajes inapropiados, anuncios, mensajes repetidos, etc.:

David Gómez (Observatorio de la Infancia de Andalucía),

Isabel Olea (EPI, León),

Julio Alonso-Arévalo (Universidad de Salamanca),

Tomàs Baiget (EPI, Barcelona).

Puedes suscribirte a IweTel en:

https://listserv.rediris.es/cgi-bin/wa?SUBED1=IWETEL\&A=1 